\title{
Ice Cream as a Vehicle for Incorporating Health-Promoting Ingredients: Conceptualization and Overview of Quality and Storage Stability
}

\section{Abstract}

Ice cream is a product with peculiar textural and organoleptic features and is highly appreciated by a very broad spectrum of consumers. Ice cream's structure and colloidal design, together with its low-temperature storage, renders it a very promising carrier for the stabilization and in vivo delivery of bioactive compounds and beneficial microorganisms. To date, many applications related to the design and development of functional ice cream have been documented, including products containing probiotics, prebiotics, synbiotics, dietary fibers, natural antioxidants such as polyphenols, essential and polyunsaturated fatty acids, and low glycemic index blends and blends fortified with mineral or trace elements. In this review, promising strategies for the incorporation of innovative functional additives to ice cream through the use of techniques such as microencapsulation, nanoemulsions, and oleogels are discussed, and current insights into the implications of matrix, processing, and digestion on bioactive compounds in frozen dairy desserts are comprehensively reviewed, thereby providing a holistic overview of the current and emerging trends in this functional food sector.

\section{Introduction}

\section{Functional foods: definitions, concepts, and trends}

Over recent years, there has been significant interest in the development of innovative food products conferring customized benefits to the consumer, that is, improving physical and mental well-being, prevention of diet-associated health complications in addition to fulfilling basic dietary function (hunger satisfaction and fulfillment of the daily nutritional need of consumers). The increased awareness of the consumer regarding health and nutrition related issues as well as the role of several food regulatory bodies to promote the production and consumption of minimally processed, healthier and more nutritious food products, appear to be steering a transformation within the food industry. Moreover, cultural, educational, and economic effects together with food quality and safety criteria have also been highlighted as drivers of consumer demand for healthy and safe food products (Fogliano and Vitaglione 2005).

Regardless of the expanding trends of the health-promoting food market, the term "functional food" still remains arbitrary, and thus several definitions have been introduced by both the research community and governmental regulatory authorities. For example, according to the American Council on Science and Health, "Functional foods can be considered to be those 
whole, fortified, enriched, or enhanced foods that provide health benefits beyond the provision of essential nutrients (for example, vitamins and minerals), when they are consumed at efficacious levels as part of a varied diet on a regular basis" (Hasler 2002). Similarly, Arihara and others (2004) and Robefroid (2000) claimed that functional foods are those that contain 1 or more compounds that can support important or limited functions in the organism, promote welfare, health, and protection from degenerative chronic disease, without, however, curing diseases. From a food product standpoint, functional foods can be generally classified into the following categories (Bigliardi and Galati 2013):

1. food fortified by nutrients such as vitamins, minerals and trace elements, antioxidants, and so on,

2. food enriched with health-promoting ingredients that commonly do not exist in the enriched food matrix such as probiotics or prebiotics,

3. reformulated food, that is, food where 1 or several ingredients associated with the adverse health impact is reduced, substituted, or removed, for example, trans-fatty acids, saturated fatty acids, antinutrients, using low glycemic index (GI) ingredients and fat replacers,

4. food that is naturally enriched by 1 or more components, for example, butter containing omega-3 fatty acids or conjugated linoleic acid (CLA).

The rapidly expanding functional food market has required a significant expansion in research and innovation within the food industry, a sector traditionally considered as having a rather low innovation level compared to pharmaceuticals. However, functional new product development (NPD) required changes to many traditional food production stages such as product strategy development, product design and development, product commercialization, product launch, and postlaunch, though it is generally accepted that many practices employed in every particular stage of NPD critically differ (Khan and others 2013). For instance, the orientation toward innovation, state-of-the-art and knowledge generation, the commercialization strategy, and establishment of collaborative networks and arrangements are only some of the differing points in the case of functional NPD (Khan and others 2013). Thus, it can reasonably deduced that the functional food industry is generally recognized by a higher level of innovation than the traditional one where innovation refers to the incremental improvement of the product rather than to a radical innovation approach.

To date, there are numerous examples of functional foods within the dairy sector, whilst noticeable innovation is also being demonstrated in the confectionary, soft-drink, bakery, and the infant food sector (Bigliardi and Galati 2013). With respect to the type of product functionalization, probiotics are the dominating functional/health-promoting ingredients for food applications followed by vitamins, minerals and trace elements, and prebiotics. Although most government regulatory bodies aim mainly to ensure the success of major dietary enhancing/balancing strategies (for example, fat, sugar, or salt reduction, increase of dietary fiber (DF) intake, and so on), the acceptance of functional food by the consumer is mainly governed by the awareness and confidence of the incorporated active substances and the overall organoleptically perceived quality and appearance. This implies that functional foods must diverge only minimally from regular food formulations in terms of sensory quality. Moreover, adding active compounds of low consumer popularity, for example, flavonoids, carotenoids, stanols, and so on, may result in poor market penetration (Granato and others 2010b). On the other hand, functional food promotion via health benefit claims may drastically increase interest, enhancing the buying intent of consumers; however, this is 
often considered not feasible in the EU, due to the existing legislation restrictions as, for example, for probiotics.

Incorporating bioactive compounds can be carried out by their direct addition to the food in free form, by using natural food matrices rich in the active compound (for example, spices, fruit, or vegetable pulp) or by adding specifically developed carriers from food grade materials (for example, microcapsules, edible films and coatings) where the active compound is physically or chemically entrapped. Finally, whatever the strategy, the end product should also meet a series of additional criteria such as enhanced stability and prolonged shelf life, cost efficiency, absence of safety concerns, and proven (ideally by means of clinical trials) bioavailability and functionality (Granato and others $\underline{2010 \mathrm{~b}}$ ).

\section{Ice cream as a vehicle for incorporating health-promoting ingredients}

Ice cream is a complex colloidal food system that in its frozen state consists of ice crystals, air cells, and partially coalesced fat droplets dispersed in a continuous freeze-concentrated aqueous (serum) phase containing polysaccharides such as galactomannans, carrageenans, cellulosics, sugars (sucrose and lactose), proteins, and minerals (especially calcium, but also sodium and potassium) (Goff 2008). Ice cream structure development and stabilization is a dynamic process where the main components, namely, biopolymers (proteins and polysaccharides), fat droplets, and water undergo significant colloidal and physical changes such as biopolymer hydration, fat droplet crystallization, ice nucleation, and crystallization, fat droplet partial coalescence, freeze-concentration, formation of cryogels, proteinpolysaccharide phase separation, formation of biopolymer entanglement (Goff 1997; Bolliger and others 2000; Chang and Hartel 2002; Patmore and others 2003; Regand and Goff 2003; Soukoulis and others 2009; Cook and Hartel 2011). In addition, it is well established that phenomena such as ice recrystallization, air cell Ostwald ripening, and lactose crystallization govern the organoleptic quality, including creaminess, grittiness, coarseness, mouth-coating, and tongue lubrication as well as shrinkage (Muse and Hartel 2004; Soukoulis and others 2008, 2010b; Varela and others 2014; Soukoulis and Fisk in press).

Over the last 2 decades, ice cream science and technology has undergone a remarkable progress exploring and understanding structure - texture - storage stability interactions on a mechanistic basis. This has enabled food technologists to fairly realize the incorporation of novel or functional ingredients in model or real ice cream systems in order, to not only provide customized technofunctionality such as viscosity enhancement, cryoprotection, emulsification, water-binding, but also to improve health-related and nutritional aspects. For example, health-promoting compounds such as probiotics (Cruz and others 2009), prebiotics (AkalIn and others 2008), DF (Soukoulis and others 2009), natural antioxidants (SunWaterhouse and others 2013), fat sources rich in polyunsaturated fatty acids (PUFAs) (omega 3/6 fatty acids) (Song and others 2011), minerals (Erkaya and others 2012), and low GI sweeteners (LGSs) (Whelan and others 2008b) have been incorporated into ice cream systems. This trend for employing ice cream as a vehicle for health-related compounds appears to be supported by the consumers' demand for healthier and more nutritious food products that lack food additives and are able to confer health benefits beyond fulfilling basic dietary demands. 
Due to its almost world-wide availability, high consumer acceptability and appealing sensory attributes, resulting in a high sales rate (5.8 billion L for the U.S. market in 2011, USDA 2012) ice cream can be regarded as a favorable vehicle for the delivery of bioactive compounds. Moreover, the implementation of generally low-temperature manufacturing steps (except for the homogenization-heat treatment), including frozen storage typically under dark conditions, renders ice cream as a good substrate for the long-term preservation of the functional traits of added health-promoting compounds, including beneficial living cells such as probiotics, reducing, for example, oxidative damage induced by light or heat.

Recently, major advances in ice cream technology, in terms of structure-texture development and stabilization, have been comprehensively reviewed (Soukoulis and Fisk in press). The aim of this review is to present recent advances in functional ice cream, a product enriched with bioactive compounds, probiotics, and their respective combinations. Strategies for the efficient incorporation of bioactive compounds and their potential impact on structure, organoleptic features, and storage stability are highlighted. In addition, recent studies on the stability/viability, digestion, and bioavailability of the particular bioactive compounds are also concisely discussed in the present work.

\section{Probiotics}

According to the FAO/WHO (2002), the term probiotic refers to live microorganisms that when orally administered in adequate amounts $\left(10^{6}\right.$ to $\left.10^{7} \mathrm{CFU} / \mathrm{g}\right)$ confer health benefits to the host. Administration of probiotics to the human host has been reported to be associated with immune system modulation, reduction of symptoms related with irritable bowel syndrome (IBS), diarrhea treatment, serum cholesterol reduction, anti-inflammatory action, and the prevention of cancer and mutagenesis (Saad and others 2013). Although health claims associated with the presence of viable bacteria in processed food are not yet having been ratified by the European Food Safety Association (EFSA), the body of evidence that certain bacteria strains from Lactobacilli and Bifidobacteria species could be health beneficial is rapidly growing.

In an attempt to satisfy the increasing market demand of probiotic-enriched food products, a vast number of applications related to dairy products such as yogurt (Cruz and others 2012; Cruz and others 2013; Pimentel and others 2013), ice cream (Cruz and others 2009), cheese and dairy spreads (Gomes and others 2011; Alves and others 2013; Esmerino and others 2013), breakfast cereals (Saarela and others 2006b), bakery (Soukoulis and others 2014) and confectionary products (Malmo and others 2013), emulsion-based preparations (Mantzouridou and others 2012), meat products (Khan and others 2011), as well as dairy and fruit beverages (Saarela and others 2006a; Granato and others 2010a, 2010b; Antunes and others 2013; Castro and others 2013; Maganha and others 2014) have been demonstrated. With respect to market share, yogurt and fermented milk beverages and fruit juices remain the largest global market share holders, while ice cream appears to be a promising product for probiotic food development (Euromonitor 2012).

The viability and therefore the functionality of probiotics is impacted by several intrinsic (species/strain, morphological characteristics of the bacteria, and their ability to produce intracellular cryoprotectants) and extrinsic (food substrate composition, exposure to heat, mechanical treatment, oxygen toxicity, and $\mathrm{pH}$ ) parameters (Fu and Chen 2011). Depending on the species, probiotic bacteria are regarded as strictly anaerobic (Bifidobacteria) or 
microaerophilic (most Lactobacilli), and therefore susceptible to high partial oxygen pressure. To date, microencapsulation of probiotics in biopolymer matrices by mechanical or physicochemical means (dehydration, emulsification, extrusion, ionic or heat-induced gelation, cross-linking, and coacervation) are the most common strategies for the delivery of probiotic efficacy to food products able to withstand severe processing steps such as thermal (heat or freezing) and mechanical (mixing, size reduction, and pumping) treatments, thermomechanical processing, storage conditions, and so on (Champagne and Fustier 2007; Burgain and others 2011). Moreover, changing the composition of the fermentation medium (such as polyols, sugars, Tween 80, and inorganic salts), controlled $\mathrm{pH}$ and temperature, growth state of the culture (logarithmic or stationary), cryopreservation and subjecting bacterial cells to heat, cold, acid, or osmotic stress and starvation, have also been proposed as alternative strategies for the cryopreservation of lactic acid bacteria (LAB) and probiotics (Pehkonen and others 2008; Siaterlis and others 2009).

\section{Methods for probiotic incorporation into ice cream}

The first attempts to incorporate viable probiotic bacteria into frozen dairy desserts were made decades ago using ice cream, fermented frozen desserts as well as their ethnic analogs (Holcomb and others 1991; Laroia and Martin 1991; Hekmat and McMahon 1992; Westerbeek 1995; Kebary 1996; Inoue and others 1998). Probiotics can be incorporated into ice cream either in free or microencapsulated form. In the first case, probiotics can be supplied by either blending an acidified/fermented milk base (such as probiotic yogurt, acidified milk, or cream) with the ice cream mix base at the onset of production, or by direct inoculation of the ice cream mix with a single or a symbiotic culture starter prior to the whipping-freezing step (Tamime and Robinson 2007; Soukoulis and Tzia 2008). Direct inoculation into the final ice cream mix might allow none, partial, or full fermentation depending on the flavor-texture quality characteristics required (Soukoulis and Tzia 2008). On the other hand, using microencapsulated probiotic bacteria, that is, in biopolymer crosslinked or spray/freeze-dried matrices facilitates the manufacturing process (no need for cultured milk base preparation). However, it can also reduce effectively the mechanical or osmotic stress that would induce injury to living cells (Hekmat and McMahon 1992; Kailasapathy and Sultana 2003; Homayouni and others 2008a). Employing microencapsulated probiotics for the production of functional ice cream has gained much attention during the last few several years due to the versatility of the method, the prolonged shelf life attained for both microcapsules and ice cream, and the minimized impact of the carrier material on the sensory, texture, and structural aspects of the finished product (Mohammadi and others 2011).

\section{Factors affecting probiotic viability in ice cream}

Several factors have been reported to significantly impact the viability of probiotic bacteria throughout processing, such as freezing processes and postfreezing (hardening and frozen storage) conditions, and additional parameters such as ice cream composition (sugars, polysaccharides, protein type, and content), $\mathrm{pH}$, and the presence of oxygen (Cruz and others 2009; Mohammadi and others 2011). Although the sublethal impact of each factor might range from negligible to fairly considerable, their combination can result in severe lethality of the probiotic living cells. It is therefore deduced that the strict control of the implemented processing practices and the compositional and structural product are essential to ensure an end-to-end cryopreservation of the probiotic microbiota (Table $\underline{1}$ ). 
Table 1. Compositional, technological, and sensory characteristics of probiotic ice cream and stability of probiotic microbiota under frozen storage and in-vitro gastrointestinal conditions

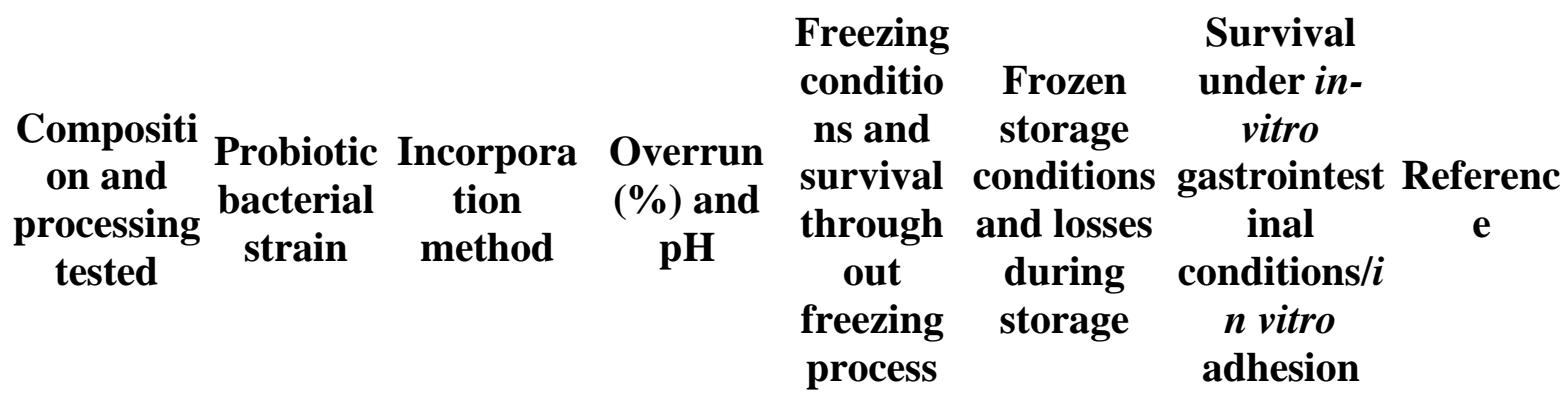

1. $\mathrm{MRS}=$ de Man, Rogosa, Sharpe agar, FOS = fructo-oligosaccharides, EA = ellagic acid, GA = gallic acid, GSE = grape seed extract, $\mathrm{PEO}=$ peppermint essential oil, $\mathrm{PPE}=$ pomegranate peel extract, $\mathrm{Nd}=$ not determined (no data), $\mathrm{MSNF}=$ milk solids nonfat.

Percentage

of

probiotic

cultured $L$.

milk added acidophil Free cells

to ice us (La-5)

cream mix

base $(25 \%$

to $75 \%$ )

$B$.

bifidum

(Bb-12)

$74 \%$ to

$88 \%$

Batch $\quad-20{ }^{\circ} \mathrm{C}$ for $\left(-5^{\circ} \mathrm{C}\right) \quad 16 \mathrm{wk}$

$\mathrm{Nd}$

Christian sen and others

(1996)

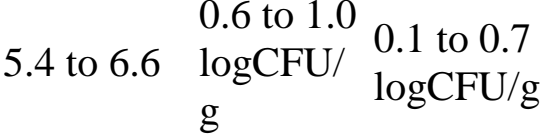

L. reuteri

$L$. acidophil

Ice cream us (La-5)

with/witho

ut $2 \%$

L. $\quad$ Free cells

glycerol

rhamnosu

$s \mathrm{GG}$

$\mathrm{Nd}$

Batch

(nd) $\quad-20{ }^{\circ} \mathrm{C}$ for

$B$.

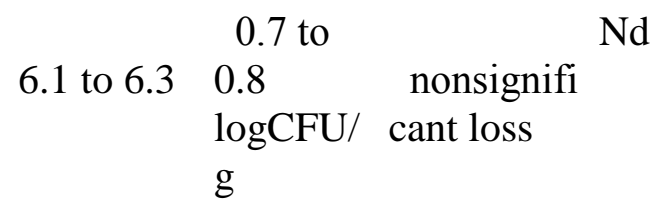

Hagen

and Narvhus (1999)

bifidum

(Bb-12)

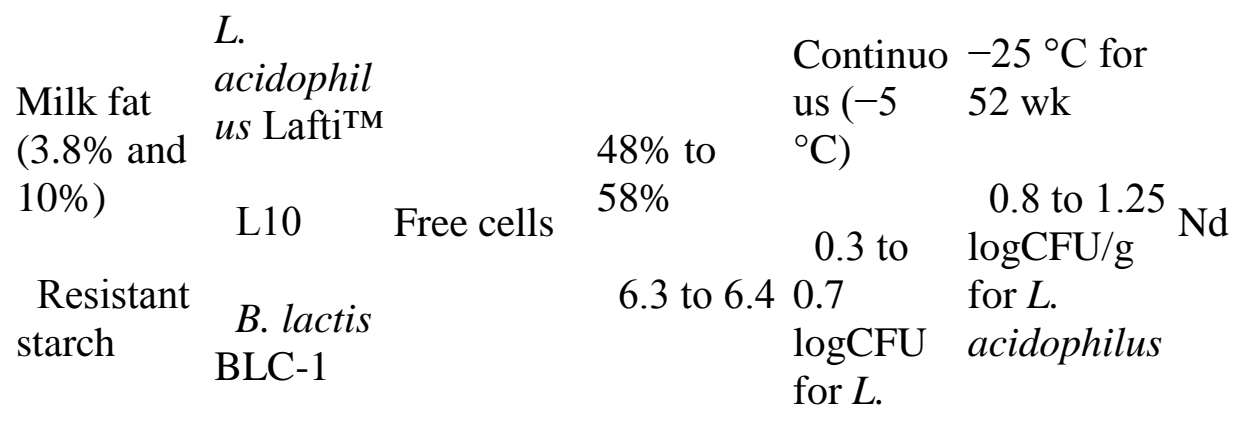

Haynes

and

Playne

(2002) 


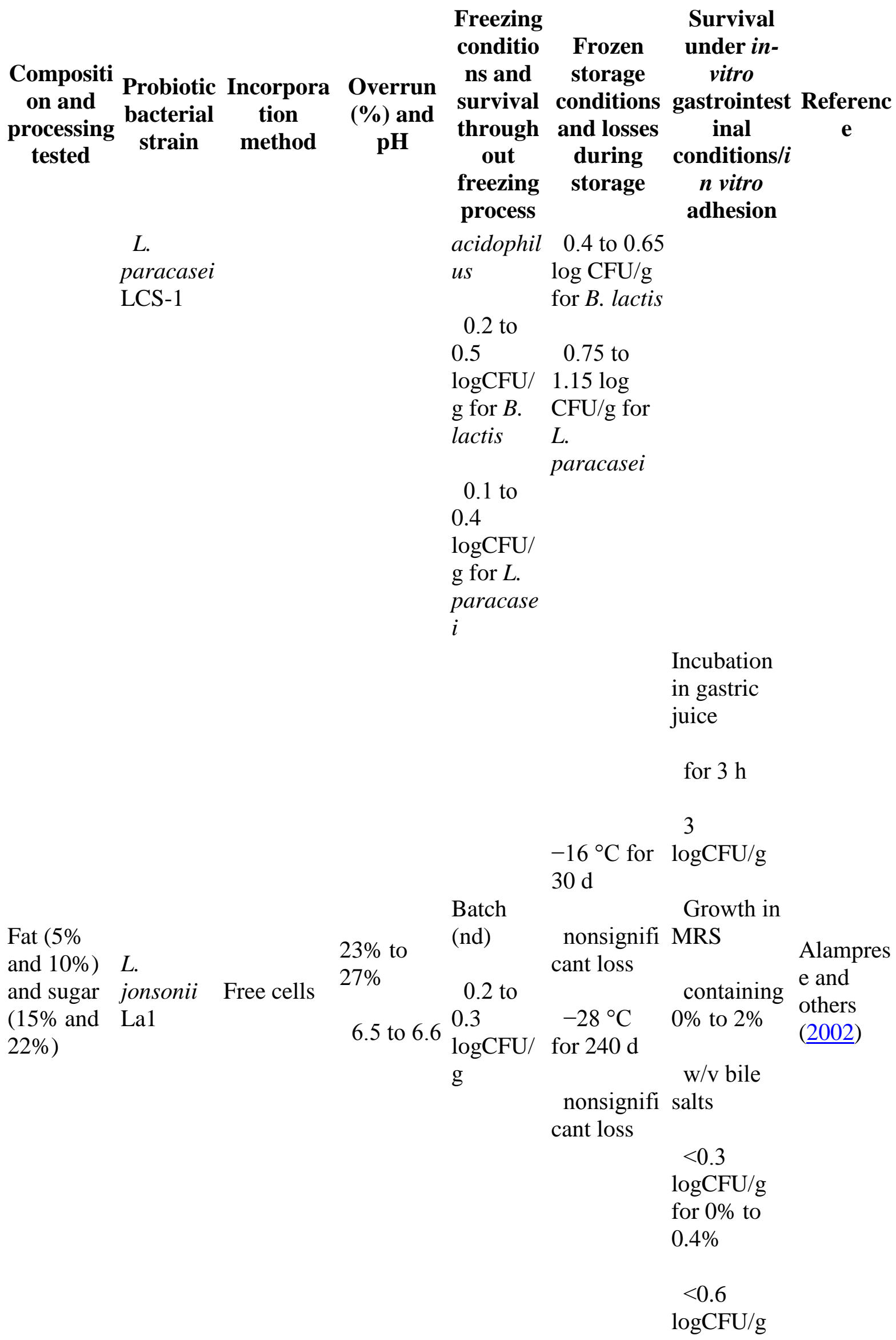




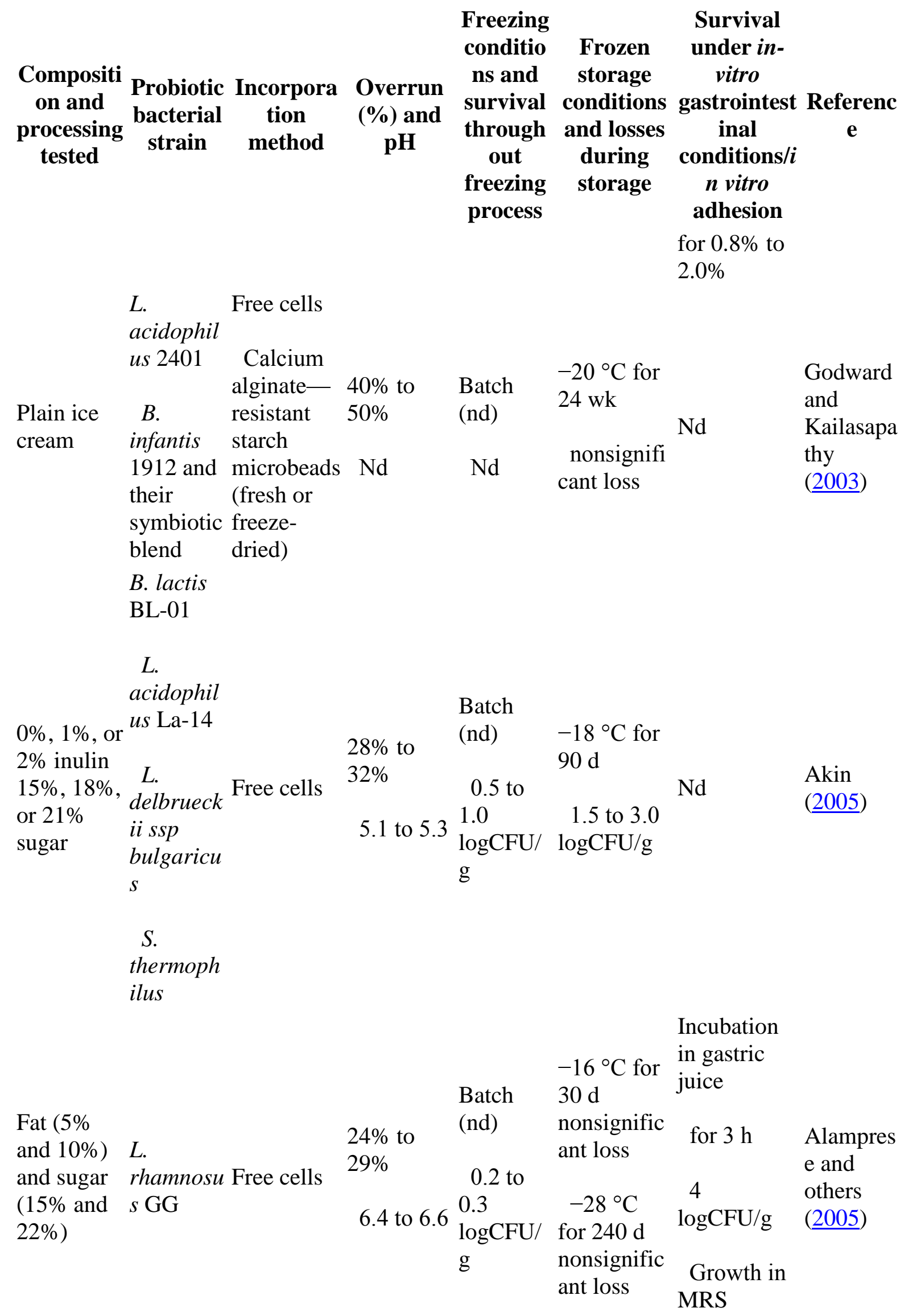




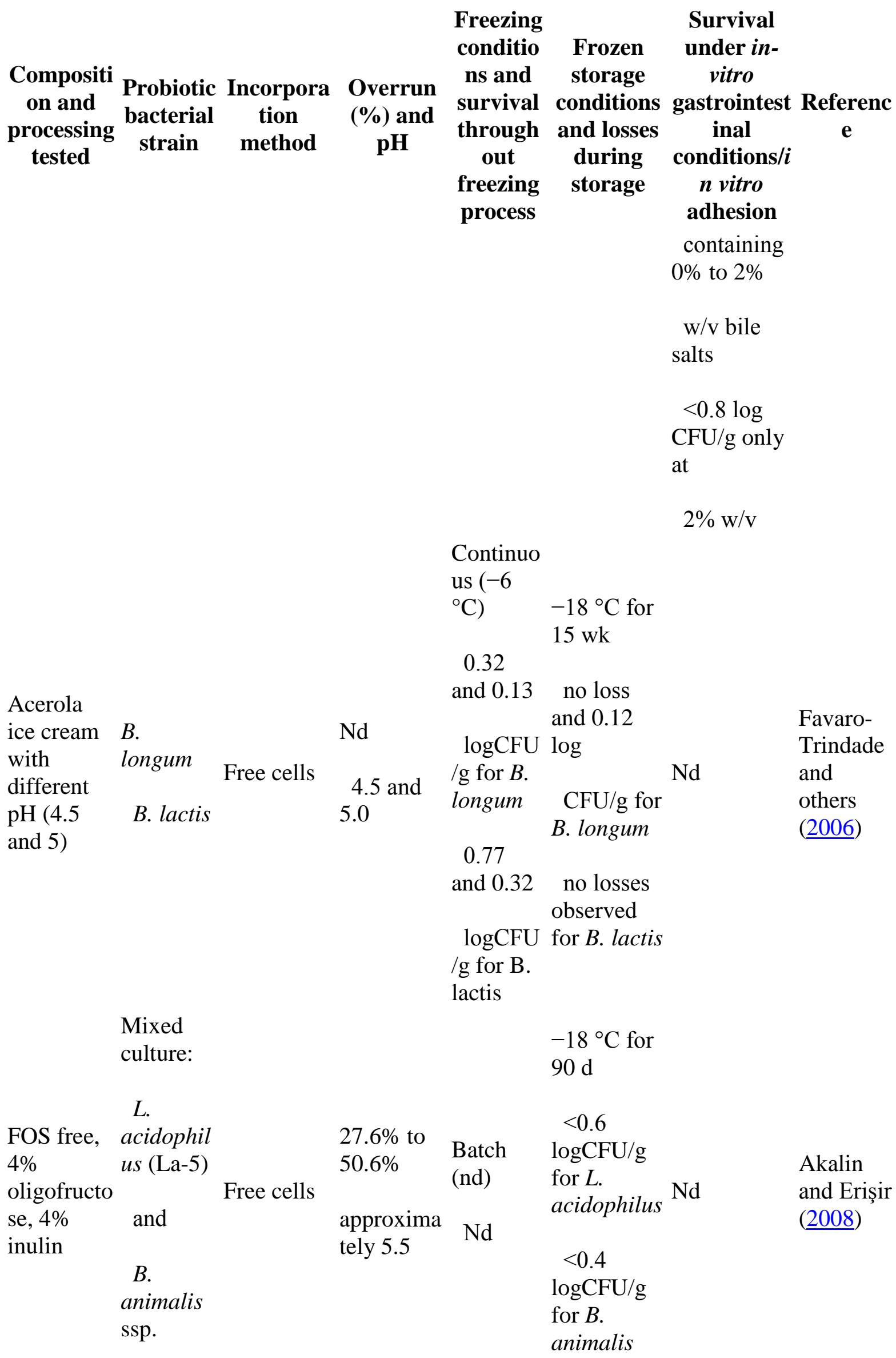




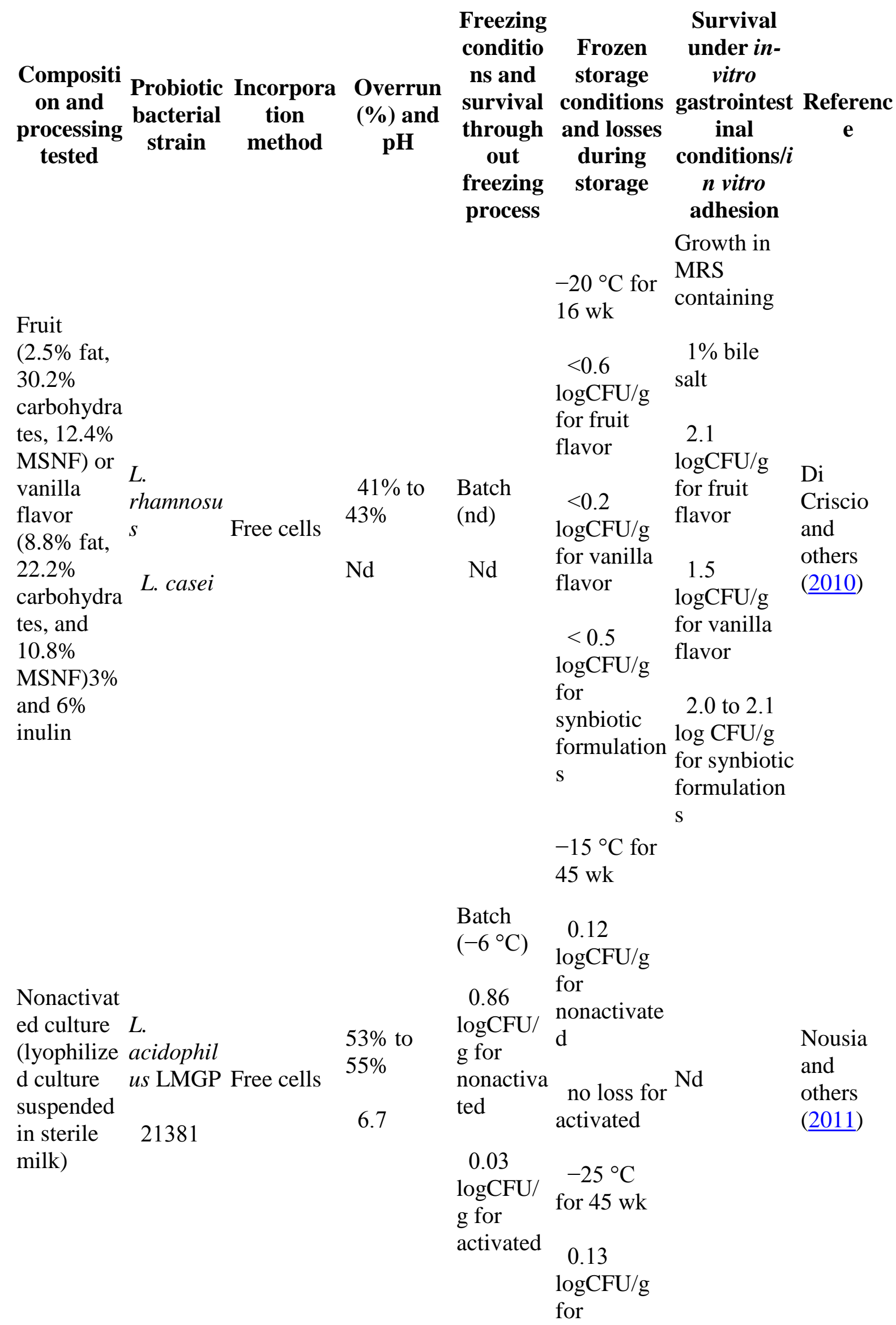




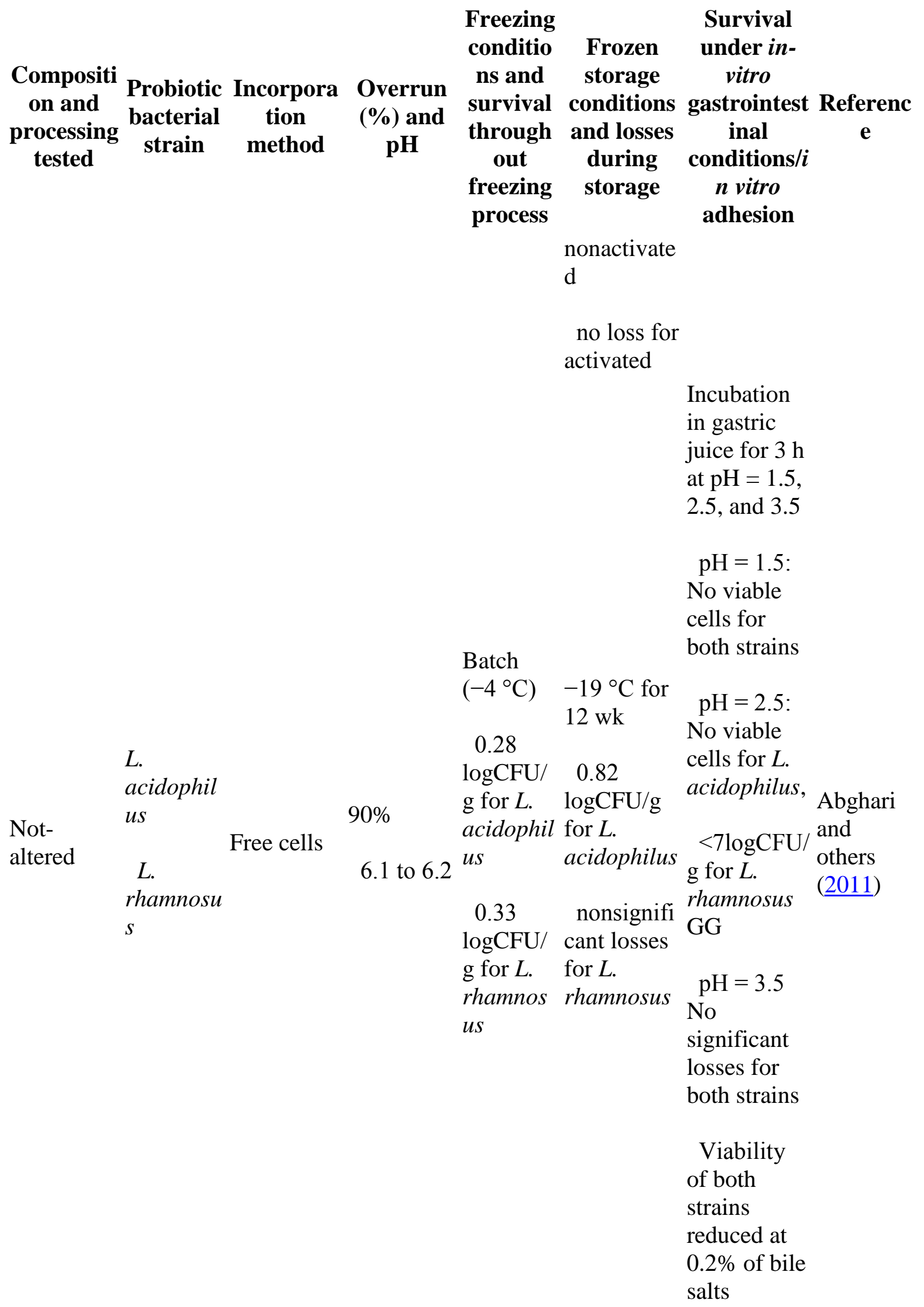

Song and others 


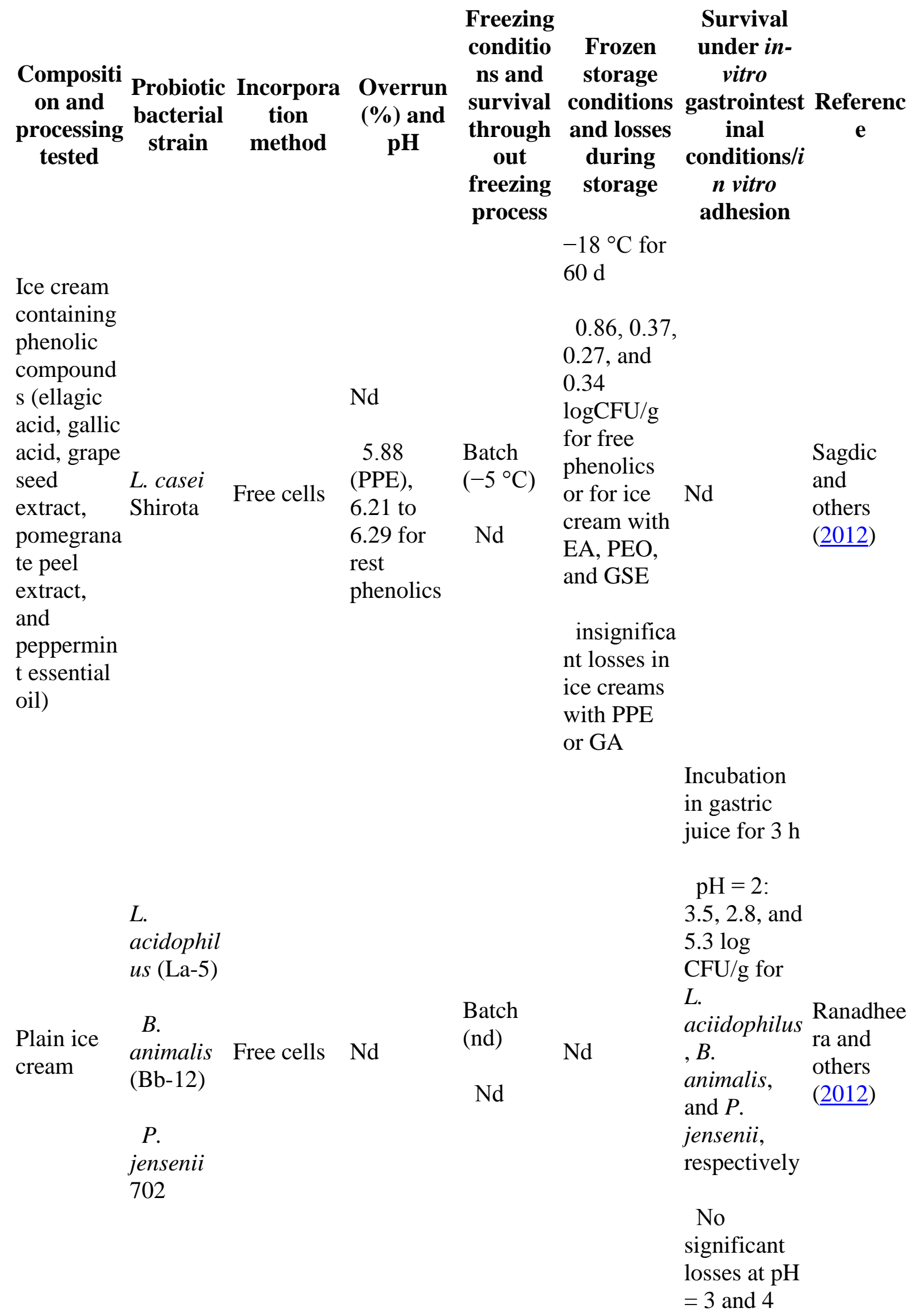




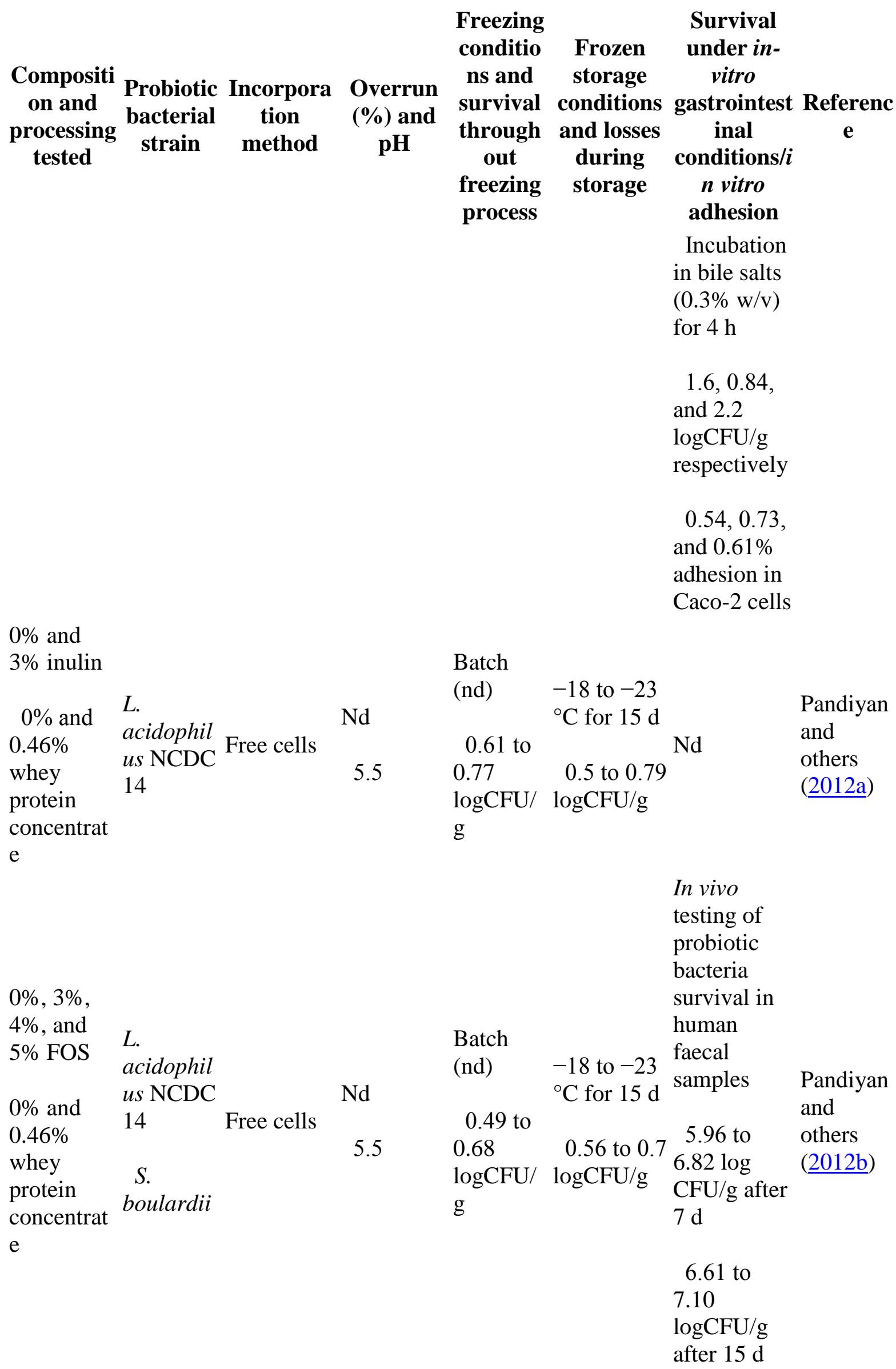




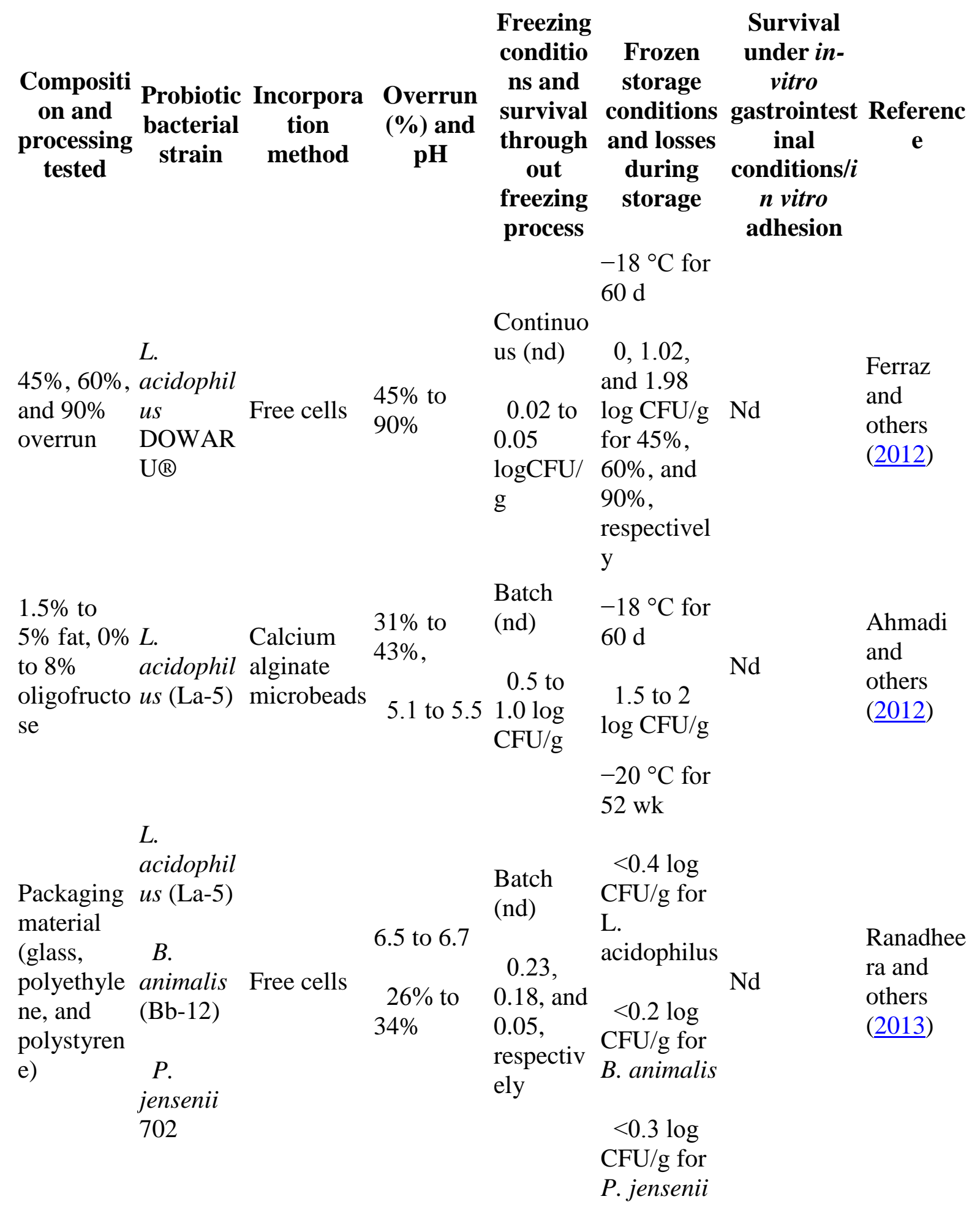

\section{Freezing process conditions}

Depending on their freeze tolerance, the sublethal injuries of probiotic bacterial cells due to the implemented freezing process may range from minor to severe. Generally, the lethality of probiotics throughout freezing is primarily associated with the occurrence of osmotic and mechanical stresses. From a mechanistic point of view, extremely high freezing rates (cold shock) may lead to increased permeability of the membranes, resulting in leakage of 
intracellular material due to intracellular and extracellular ice formation, inducing mechanical damage of the cell membrane. The freeze concentration of the intracellular solutes can also modify $\mathrm{pH}$, ionic strength, and concentration of several compounds, leading to toxic effects (Bremer and Ridley 2004). On the other hand, low freezing rates associated with slow supercooling and low ice nucleation have been also reported as being associated with plasmolysis, for example, intracellular water loss driven by high osmotic pressure gradients. In addition, intrinsic factors inherently associated with the freezing process, such as type of freezer (batch or continuous), freezing rate, dasher type, and whipping conditions, are well known to have a strong impact on probiotic viability (Sheu and others 1993; Ferraz and others 2012). It is generally accepted that adequately high freezing rates are required to minimize sublethal injuries of the bacterial cells. Although data relating to the effect of freezing processes are rather scarce, Sheu and others (1993) showed that continuous freezing enhances only slightly the survival of Lactobacillus delbrueckii spp. bulgaricus compared to batch freezing (55\% and 50\% survival after freezing, respectively). The former may be attributed mainly to higher ice nucleation in the case of continuous freezing, allowing the formation of a large number of small-size ice crystals (both in intra- and extracellular domains), minimizing mechanical rupture of the cell membranes by interpenetrating ice crystals (Bremer and Ridley 2004). Moreover, ice cream hardening (the rapid cooling process at the end prior to storage) had a minor impact on bacterial cell lethality, ranging from $10 \%$ to $15 \%$ regardless of the freezing process (continuous or batch) implemented (Sheu and others $\underline{1993})$.

The developing shearing forces during the freezing process may also lead to sublethal injuries of probiotics due to mechanical rupture of the cell membranes, particularly in processes enabling very high shear stress, as with low temperature extrusion (LTE) freezing. Recently, the high-pressure low-temperature (HPLT) technique has been successfully applied for the production of ice cream with good air cell and ice crystal recovery, thus improving sensory properties (Volkert and others 2012). The method has also been previously applied in the production of anhydrobiotics, such as freeze-dried skim milk matrices containing $L$. rhamnosus $G G$ (Volkert and others 2008). This may be an emerging method for the development of functional frozen dairy desserts with maximal viability of living cells.

\section{Compositional features of ice cream mix}

Ice cream components able to modify the colligative properties of the ice cream mixture (sugars, polyols, oligosaccharides, and proteins) can directly or indirectly affect the cryopreservation of probiotics. Nevertheless, these ingredients are deemed as cryoprotectants - many of which are used extensively for cell lyophilization - and it should be noted that their combined effect on ice crystallization, freeze concentration, and ice recrystallization has an impact on cryoprotection (Santivarangkna and others 2008). For instance, though polyols are regarded as efficient compounds for minimizing cellular injury during ice crystallization, their performance could be restricted during frozen storage due to their poor ability to control ice recrystallization. Similarly, ingredients that elevated the glass transition temperature (polysaccharides/high-molecular-weight sugars ensuring maximal stability of the probiotics in the rubbery/glassy matrix during frozen storage) might also induce high osmotic stress due to freeze concentration of the serum phase (Pehkonen and others 2008).

The majority of studies investigating survival of probiotic bacteria (in real or model ice cream systems) have revealed that Bifidobacteria are more freeze-resistant than Lactobacilli or 
Saccharomyces (Hekmat and McMahon 1992; Başyiğit and others 2006; Akin and others 2007; Akalin and Erişir 2008; Homayouni and others 2008b). Homayouni and others (2008b) reported that storing probiotic ice cream at $-20^{\circ} \mathrm{C}$ for 6 mo was associated with higher inactivation rates of $L$. casei compared to Bifidobacterium lactis. Magariños and others (2007) demonstrated that freezing (scraped-surface freezer, $-10{ }^{\circ} \mathrm{C}$ draw temperature) resulted in lower viability of $L$. casei compared to B. animalis, whereas no significant changes on the inactivation rates of both species upon frozen storage were observed.

Increasing sugar or fat content in order to enhance texture or structural features has been reported to moderately impact probiotic cell viability. Alamprese and others (2002) did not observe any significant effect of sugar/fat content on the viability of $L$. johnsonii La1 in ice cream stored for $180 \mathrm{~d}$ at $-28{ }^{\circ} \mathrm{C}$. Similarly, the presence of sucrose or aspartame in acidified ice cream did not affect viable counts of a symbiotic/probiotic blend composed of $L$. acidophilus and L. rhamnosus during $180 \mathrm{~d}$ at $-20{ }^{\circ} \mathrm{C}$ (Başyiğit and others 2006). On the other hand, Akin and others (2007) found that $18 \% \mathrm{w} / \mathrm{w}$ of sucrose was required to ensure maximal survival of mixed strains of LAB and bifidobacteria, regardless of the species/strain. In model ice cream systems, Homayouni and others (2008b) demonstrated that probiotic osmotolerance in the presence of sucrose up to $25 \% \mathrm{w} / \mathrm{w}$ is strain- and type-dependent, with Lactobacilli (L. casei, L. acidophilus-La5) exhibiting a higher sugar tolerance than Bifidobacteria (B. bifidum and B. longum). However, including a very strong osmolytic agent $(2 \% \mathrm{w} / \mathrm{w}$ glycerol) has been reported to have a negligible effect on the cryopreservation of mixed probiotic bacteria (L. acidophilus and B. bifidum) during freezing and storage $\left(-20^{\circ} \mathrm{C}\right.$, $52 \mathrm{wk}$ ), while remarkably higher amounts of the cryoprotectant were required to achieve a significant cryoprotective effect (Hagen and Narvhus 1999).

Prebiotic fiber such as fructooligosaccharides (FOS), galactooligosaccharides (GOS), and resistant starch have also been tested as potential cryoprotective agents and as probiotic growth and activity stimulants in the gut environment for ice cream systems (Akin 2005; Akin and others 2007; Akalin and Erişir 2008). Inulin and oligofructose are the most common prebiotics implemented in probiotic ice cream production due to their established physiological aspects (modulation of gut flora bifidogenicity, suitability for diabetics, potential cancer prevention, improved mineral absorption, and improved lipid metabolism) and specific technological properties allowing their use as fat mimetics, sugar replacers, texturizers, mouthfeel improvers, and stabilizers (Coussement and Franck 2001; Franck 2002). The literature on FOS functionality in probiotic ice cream is rather contradictory; Akalin and Erişir (2008) reported a significant improvement of the viability of $B$. animalis Bb-12 and L. acidophilus La-5 during $90 \mathrm{~d}$ of storage at $-18^{\circ} \mathrm{C}$ in the presence of $4 \%$ oligofructose, while no remarkable changes in viable counts of probiotic microflora were observed when inulin (4\%) was added.

Akin and others (2007) revealed a strain dependency of the impact of inulin on the viability of the ice cream microflora. While the viability of yogurt culture starters (L. delbrueckii spp. bulgaricus and $S$. thermophilus) was not significantly improved by inulin (up to $2 \% \mathrm{w} / \mathrm{w}$ ), a noticeable improvement was detected for L. acidophilus and B. lactis. On the other hand, in studies by Di Criscio and others (2010) and Ahmadi and others (2012), supplementation of probiotic ice cream with prebiotic fiber (inulin) did not exhibit any stimulating activity for $L$. acidophilus-La5, L. rhamnosus, and L. casei.

\section{pH and ionic strength}


Modulating the $\mathrm{pH}$ of the ice cream mix is another important factor that influences the survival of probiotics, particularly for hardened products. The decrease of $\mathrm{pH}$ is due to the metabolic activity of the microflora (producing lactic and/or acetic acid via the EmdenMeyerhof-Parnas pathway) or due to inclusion of acidic preparations (fruit juices, purees, or syrups) (Marshall and others 2003). Generally, based on manufacturing practices, the $\mathrm{pH}$ of probiotic ice cream might vary from 4.5 to 6.3 for fully fermented and unfermented formulations, respectively (Soukoulis and Tzia 2008). It is well established that Lactobacilli are more acid-tolerant than Bifidobacteria; consequently, a pH of 5.0 or higher, or 5.5 and higher, is usually recommended for probiotic ice creams, respectively (Laroia and Martin 1991). On the other hand, it has been shown that using symbiotic cultures (mixtures of LAB and probiotic bacteria) instead of single probiotic starter cultures can surmount the adverse results of acidic environmental conditions on probiotics (Davidson and others 2000).

Favaro-Trindade and others (2007) deduced that the freeze-induced injuries of L. acidophilus (74-2 and LAC4) were minimized in low-pH ice cream formulations containing added yellow mombin pulp (4.5 compared with 5.0), whereas the $\mathrm{pH}$ did not modify bacterial cell inactivation rates upon storage at $-18{ }^{\circ} \mathrm{C}$ for $105 \mathrm{~d}$. In a previous study, the same research group had demonstrated an improved viability of B. longum and B. lactis in low-pH (4.5) ice creams containing acerola pulp. However, it should be noted that in both studies, the initial load of viable bacteria in the fully fermented systems ( $\mathrm{pH} 4.5)$ was higher due to a prolonged incubation time, a factor well known to influence cell injuries during freezing (Santivangkna and others 2008). The incorporation of symbiotic cultures (L. acidophilus, B. longum, and $S$. thermophilus) in ice cream has been reported as a good strategy for reducing the lethal effects of frozen storage on probiotics as measured by the $\beta$-galactosidase enzyme activity (Kailasapathy and Sultana 2003). Davidson and others (2000) also demonstrated the synergistic action between $\mathrm{LAB}$ and probiotic bacteria by means of freeze tolerance although the authors did not observe a significant impact of the $\mathrm{pH}$ on bacterial cell recovery over 11wk storage at $-20^{\circ} \mathrm{C}$.

\section{Presence of oxygen}

The presence of oxygen primarily due to air incorporation during the freezing-whipping step and secondarily due to oxygen dissolution in the ice cream mix during processing, including blending, homogenization, pumping, and oxygen permeation through the packaging material is another well-established route inducing bacterial death (Talwalkar and Kailasapathy 2004). Although the amount of air incorporated (also referred as overrun) varies according to the adopted manufacturing practices and the required structurization/texturization, it usually ranges from $20 \%$ for artisanal ice cream (gelato) to $50 \%$ to $100 \%$ for industrial frozen dairy desserts (Marshall and others 2003; Goff 2008). The lack of oxygen-scavenging cellular functionality in probiotic bacteria explains the toxic effect of oxygenic metabolites, such as superoxide anion $\left(\mathrm{O}_{2}^{-}\right)$, hydroxyl radicals $\left(\mathrm{OH}^{-}\right)$, and hydrogen peroxide $\left(\mathrm{H}_{2} \mathrm{O}_{2}\right)$ in the cells (Mills and others 2011). In a recent study by Ferraz and others (2012), it was demonstrated that an overrun of $45 \%$ or less does not modify significantly the load of viable L. acidophilus DOWARU® cells for a storage period of $60 \mathrm{~d}$ at $-18^{\circ} \mathrm{C}$. A further increase of the overrun (60\% to 90\%) induced a significant reduction of microbial cells ranging from 1.02 to $1.98 \mathrm{log}$ $\mathrm{CFU} / \mathrm{g}$ after $60 \mathrm{~d}$ of storage at $-18{ }^{\circ} \mathrm{C}$. Generally, the strictly anaerobic Bifidobacteria are pronouncedly more vulnerable to oxygen than Lactobacilli, which was also confirmed for aerated dairy desserts including ice cream (Homayouni and others $\underline{2008 \mathrm{~b}}$ ), although lethality of the latter depended on the employed strain. It was shown that L. rhamnosus and L. casei exhibited a higher oxygen tolerance than L. acidophilus in unfermented ice creams 
(Homayouni and others 2008b; Abghari and others 2011). However, the presence of oxygen scavenging compounds (for example, L-cysteine, L-ascorbic acid, whey proteins, acid casein hydrolysate, catechins, and polyphenols) is regarded as effective for ensuring the survival of probiotic bacteria in dairy matrices including ice cream (Ravula and Shah 1998; Homayouni and others 2008b; Sagdic and others 2011; Gaudreau and others 2013; Pandiyan and others 2012c; Soukoulis and others 2014). Microencapsulation of probiotics also showed to hinder the formation of oxygenic metabolites in dependence of the encapsulant and the probiotic species/strain. For example, Shah and Ravula (2000), Homayouni and others (2008b), and Ahmadi and others (2012) found that the survival rates of microencapsulated probiotic cells in matrices composed of sodium alginate or binary blends of sodium alginate with either resistant starch or FOS significantly improved compared to unprotected bacterial cells. In addition, Godward and Kailasapathy (2003) demonstrated that symbiotic cultures instead of single or mixed probiotic strains can provide better cryoprotection and metabolic activity preservation compared to both free and encapsulated systems.

\section{Impact of probiotics on quality characteristics of ice cream}

Quantity and quality of ice cream mix components, together with the structure development process during the freezing-whipping step, are the most crucial factors that control the quality characteristics of ice cream (Marshall and others 2003). In this context, adding probiotics without any preacidification prior to freezing would not be expected to impact flavor-taste characteristics of the final product, as probiotic cells would not exert any remarkable metabolic activity leading to the formation of volatile and nonvolatile flavor compounds. On the other hand, incorporating probiotics into partially/fully prefermented ice cream base, or immobilized within biopolymers, can improve the textural and sensory properties of ice cream. Specifically, increase of mix viscosity, enhancement of melting resistance, development of peculiar organoleptic properties such as refreshing and pleasantly sour flavor, improved body and controlled iciness, and ice crystal-induced grittiness have been reported (Christiansen and others 1996; Christiansen and others 1999; Aryana and Summers 2006; Salem and others 2006).

\section{Unfermented probiotic ice creams}

It is generally accepted that the addition of probiotics to plain ice cream mixes does not change composition, the viscosity, and physicochemical characteristics of the ice cream mixes, or the overrun values and instrumental texture profile of the finished frozen products (Alamprese and others 2002; Godward and Kailasapathy 2003; Alamprese and others 2005; Homayouni and others 2008a; Di Criscio and others 2010; Pandiyan and others 2012b). Minor or nonperceivable sensory changes (appearance, texture, body, flavor, and aroma) have been reported in a series of studies conducted using unfermented ice creams (Alamprese and others 2002; Di Criscio and others 2010; Ferraz and others 2012; Homayouni and others 2012; Pandiyan and others 2012b). Apparently, the low bacterial volume is insufficient to cause any significant change in the structure of the ice cream.

However, according to the studies of Di Criscio and others (2010) and Pandiyan and others $(\underline{2012 b})$, probiotic ice cream was rated as less appealing in terms of taste and aroma. In addition, Di Criscio and others (2010) demonstrated that the sensory profile of probiotic ice cream was strain-dependent, with the L. casei formulation was better perceived in terms of 
taste compared to L. rhamnosus GG. Triangle test sensory analysis of ice creams with or without added $L$. rhamnosus GG showed that probiotic ice cream was significantly different than plain ice cream although no perceivable "probiotic" off-flavors were reported (Alamprese and others 2005).

\section{Fermented probiotic ice creams}

Contrarily to nonacidified probiotic ice cream, the fermentation of the ice cream mix either by yogurt or symbiotic culture starters is associated with important colloidal, physicochemical, textural, flavor, and taste changes (Tamime and Robinson 2007). Thus, physicochemical phenomena such as gelation, casein micelle destabilization, formation of protein aggregates, protein-polysaccharide crosslinking, milk-protein interactions at the water-oil interface, and formation of fermentation metabolites such as exopolysaccharides (EPS), lactic acid, and volatile organic compounds, have been reported to occur throughout fermented ice cream production (Christiansen and others 1996; Christiansen and others 1999; Salem and others 2006).

Parameters such as inoculum size, fermentation conditions, and $\mathrm{pH}$ endpoint, and the use of ropy (EPS-producing) strains have been reported as having a significant effect on the viscosity development of ice cream mix. Aryana and Summers (2006), investigating the impact of inoculum $(0 \%, 0.002 \%, 0.02 \%$, and $0.2 \% \mathrm{v} / \mathrm{v})$ on several physicochemical properties of probiotic ice cream, observed a significant decline of viscosity when $0.2 \%$ or $0.02 \% \mathrm{v} / \mathrm{v}$ of a symbiotic culture (L. acidophilus, Bifidobacterium, and L. casei) was used. Experimental data dealing with the effect of acidification (evaluated by endpoint $\mathrm{pH}$ and titratable acidity) on the macroviscosity of probiotic ice cream mixes are contradictory. Typically, similar or lower viscosity, compared to the noninoculated samples, was found in fermented ice cream mixes using non-EPS-producing probiotic bacterial strains (Aryana and Summers 2006; Guner and others 2007). Contrarily, Salem and others (2006) demonstrated that blending ice cream mixes with fortified single-strain probiotic milk can result in a significant increase of the viscosity in the aged ice cream mixes. The authors found that the impact on viscosity was strain-dependent, with $L$. gasseri, L. rhamnosus, and L. reuteri imparting the largest thickening effect compared to L. acidophilus and B. bifidum.

On the other hand, the in situ use of ropy probiotic cultures has also been pinpointed as an effective strategy to enhance macroviscosity of probiotic ice cream mixes (Christiansen and others 1999; Goh and others 2008). Christiansen and others (1999) showed that the use of EPS-containing milk synthesized by Lactococcus lactis ssp. cremoris can successfully replace stabilizers when blended with plain (nonstabilized) ice cream mix at a ratio of $1: 4$. Ropy milk presence induced a significant viscosity increase of the final mix, mimicking the action of polysaccharides. Similarly, Goh and others (2008) reported a thickening effect on ice cream mixes by L. delbrueckii, comparable to that of stabilized ( $0.15 \%$ locust bean gum, $0.09 \%$ guar gum, and $0.01 \% \mathrm{w} / \mathrm{w} \kappa$-carrageenan) ice cream.

In addition, the use of EPS-producing probiotic culture starters has been reported to impact the whipping ability of the ice cream mixes, overrun, and melting behavior of the finished frozen products (Christiansen and others 1999). Blending of ice cream mix (0.5\% commercial stabilizer), with ropy milk at the ratio of $1: 4$ resulted in ice creams with acceptable body and texture, slightly perceivable iciness, high shape retention and melting resistance $(17.5 \%$ compared with $10.3 \%$ ), though the molten ropy milk-based systems had a slightly curdled appearance (Christiansen and others 1999). In a previous study, Christiansen and others 
(1996) reported that ice cream mixes containing up to 50\% of probiotic ropy milk were associated with reduced air incorporation ability that was attributed to protein aggregation due to their lower $\mathrm{pH}$ value. Contrarily, Goh and others (2008) reported that fermented ice creams produced using different types of EPS-producing LAB had significantly higher overrun values than the control ones. Investigating the interrelationship between the viscoelastic profile of the ice cream mixes and the air-water interface interactions, the authors suggested that the molecular properties of the EPS formed by the ropy strains can influence significantly the air cells development and stability during the freezing process. The presence of EPS in the unfrozen serum phase was associated with foam colloids of high elastic modulus $\left(G^{\prime}\right)$ enabling the stabilization of the formed fine air cells (Goh and others 2008). However, it should be noted that in the case of acidified ice creams produced using a nonropy culture starters, air incorporation appears to be hampered proportionally to the extent of protein aggregation due to $\mathrm{pH}$ lowering (Goh and others 2008; Soukoulis and Tzia 2008).

\section{Stability of probiotic bacteria during ice cream digestion as investigated by in vitro methods}

An important aspect of the probiotic concept is the delivery of a large number of viable bacteria to the colon, thereby demonstrating cell survival upon during oral, gastric juice and intestinal phase transit. Despite the large number of studies investigating probiotic survival throughout ice cream manufacture, literature data on the ability of ice cream to deliver probiotic efficacy under simulated gastrointestinal tract (GIT) conditions (an accepted model to estimate survival rates of bacteria in vivo) (Cook and others 2012) are rather scarce. Maintaining probiotic viability under GIT conditions can be as challenging as cryopreservation, depending on the severity of the changes taking place following ingestion and particularly after the dissolution/disintegration of the matrix, exposing the released bacterial cells to the comparably harsh GIT conditions.

Oral processing leads to meltdown of the ice cream and its dilution with saliva, partial $\alpha$ amylase-facilitated breakdown of complex carbohydrates and fat droplet coalescence takes place (Stokes and others 2013). This implies (except for probiotic ice cream systems where the bacterial cells are microencapsulated) that living cells are immediately exposed to GIT conditions.

It has been demonstrated that both gastric juice and bile salts during small intestinal digestion might induce a significant reduction of viable bacteria. However, it has been widely attested that the passage through the stomach is the most critical factor for delivering probiotic efficacy to the human host (Cook and others 2012). The varying harshness of gastric conditions including transit time (several minutes for liquid meals to ca. 2 to $3 \mathrm{~h}$ for solid meals) and $\mathrm{pH}$ (about 1.6 in fasting and $\mathrm{pH} 5$ during the fed state) modulate the survival of probiotics, whereas their embedding in acid-resistant biopolymer matrices such as microcapsules and uncoated or lipid bilayered dry microparticles can provide protection against matrix disintegration during gastric passage (Cook and others 2012).

After passage through the stomach, probiotic cells enter the small intestine where $\mathrm{pH}$ and transit time are also variable, although $\mathrm{pH}$ conditions are considered less harsh than those of the gastric phase, ranging between 6.8 (duodenum) and 7.5 (ileum) (Cook and others 2012). In the small intestine, the most toxic parameter is bile salts originating from the gall bladder. Due to their interfacial properties, bile salts can alter the conformation of cell membrane 
proteins (inducing protein misfolding or denaturation) and interact with membrane lipids, modifying the structural integrity and permeability of the cell membranes ( $\mathrm{Li} 2012$ ). Moreover, bile salts have been reported to generate oxygen-free radicals, thereby altering RNA secondary structure and inducing DNA damage (Begley and others 2005).

dos Santos Leandro and others (2013) tested the viability of L. delbrueckii UFV H2b20 incubated under simulated GIT conditions ( $3 \mathrm{~h}$ in gastric juice, $\mathrm{pH}=3.0$ ) followed by a $12 \mathrm{~h}$ incubation in MRS broth (containing $0.3 \% \mathrm{w} / \mathrm{w}$ bile salts) and reported very good strain resistance in both cases ( 8.80 to $8.90 \log \mathrm{CFU} / \mathrm{g}$ and 9.1 to $9.2 \mathrm{logCFU} / \mathrm{g}$, respectively). The authors also reported that the fat content of the product did not significantly affect the strain's survivability.

In a comprehensive study, Ranadheera and others (2012) evaluated the impact of gastric $\mathrm{pH}$ $(2.0,3.0$, and 4.0$)$, bile salt concentration $(0 \%$ and $0.3 \%, \mathrm{w} / \mathrm{w})$, and matrix system (ice cream and plain and fruit yogurt) on the viability of probiotic bacteria (L. acidophilus La-5, $B$. animalis Bb-12, and Propionibacterium jensenii 702). The authors demonstrated that the bacterial viability was largely affected (viability loss $>4$ logCFU/g) only at low $\mathrm{pH}(2.0)$, with $B$. animalis $\mathrm{Bb}-12$ and $P$. jensenii 702 showing good acidic tolerance. This was mainly attributed to either the intrinsic resistance of probiotics at moderately acidic environments or the lower activity of pepsin at higher $\mathrm{pH}$ values. In the presence of bile salts, a viability loss up to $2 \log \mathrm{CFU} / \mathrm{g}$ was noted, with $\mathrm{B}$. animalis $\mathrm{Bb}-12$ being the least vulnerable. With respect to the food matrix, it was deduced that ice cream generally provides good protection against GIT conditions due to the peculiar compositional features of ice cream, namely, high milk fat content, presence of polysaccharides, and cocoa powder in the case of chocolate flavor formulations. In a series of studies, Alamprese and others $(2002,2005)$ investigated several growth inhibitors known to influence gut colonization by probiotics, including bile salts, antibiotics, and sodium dodecyl sulfate (SDS) on the survival of L. johnsonii La1 and $L$. rhamnosus GG. Both strains showed that high resistance to most of the tested stress factors, and only at very low $\mathrm{pH}$ values $(\mathrm{pH}=1.5)$ was a detectable decrease in survival observed (approximately $4 \log \mathrm{CFU} / \mathrm{g}$ ).

Ranadheera and others (2012) observed a strain and matrix dependency when scrutinizing the effect of dairy matrix on the adhesion properties of L. acidophilus La-5, B. animalis Bb-12, and $P$. jensenii 702 to Caco- 2 cells. The probiotic bacteria used in probiotic ice cream exerted satisfactory adhesion ability (Figure 1) that was slightly lower than that of fruit stirred yogurt but higher than that of plain yogurt. Although it was not fully elucidated how ice cream improves the adhesion properties of probiotic cells, it was highlighted that prolonged frozen storage did not adversely impact adhesion ability. In another study, Deepika and others (2011) investigated the adhesion ability of L. rhamnosus GG to hexadecane (a marker of the bacterial cell surface hydrophobicity) and Caco-2 cells as influenced by the matrix (yogurt and ice cream with different fat and sugar contents) and storage time. The hydrophobicity of the bacterial cell surface in both systems increased during the first $3 \mathrm{~d}$ of storage, whereas a significant reduction was observed after the 1 st wk of storage. No significant impact of matrix components (fat and sugars) was detected except for sugar-free and fat-free systems (lower surface hydrophobicity). The adhesion ability of L. rhamnosus GG to Caco-2 cells reached the highest level after $3 \mathrm{~d}$ of storage, while no impact of the fat or sugar content was detected. Yogurt is generally a better substrate for enhancing the adhesion properties of $L$. rhamnosus GG mainly because of the lower surface charge of the cells under acidic conditions (assessed by $\zeta$-potential measurements) prevailing in yogurt, thus favoring adhesion primarily via hydrophobic and less via electrostatic interactions. 

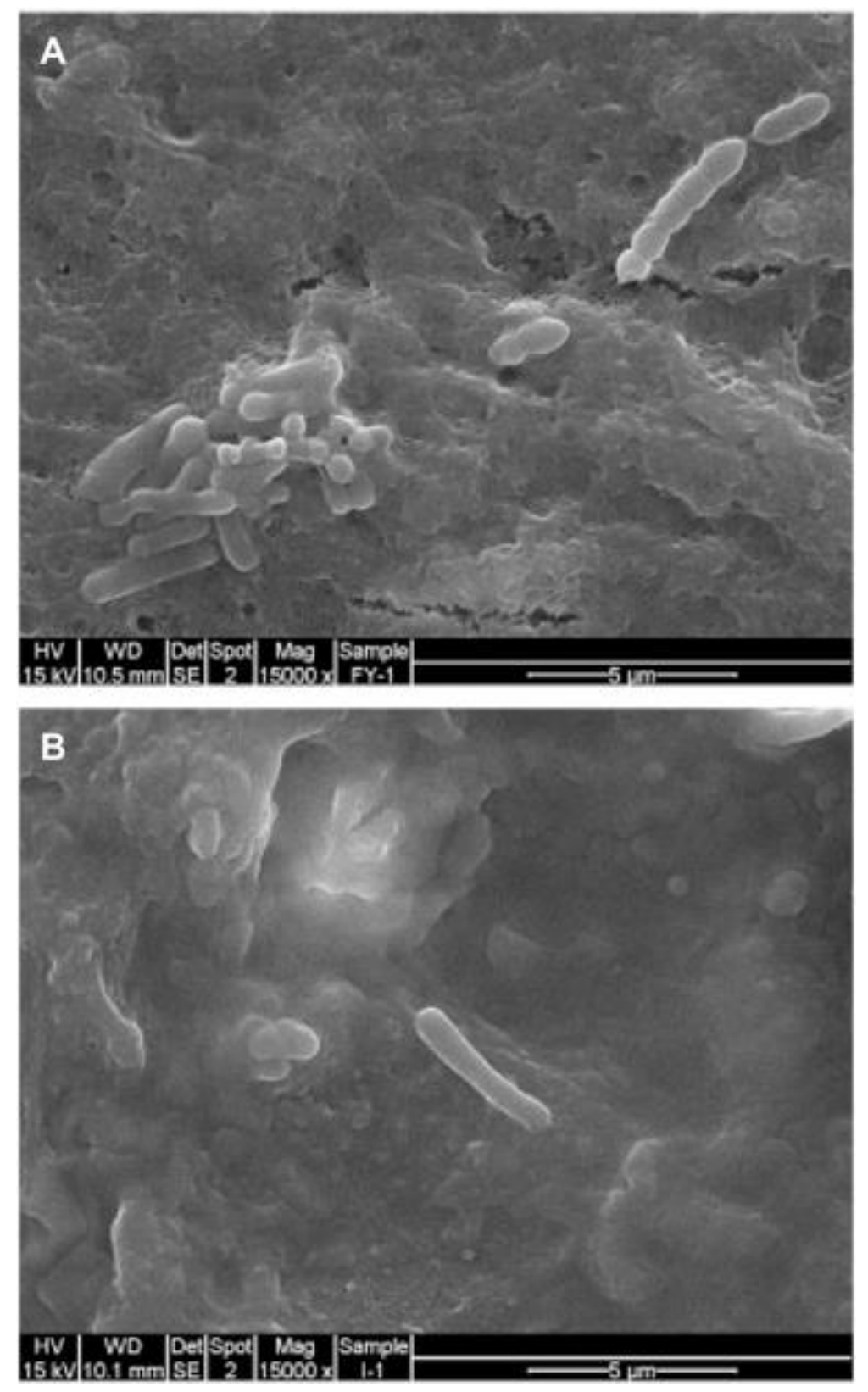

Figure 1. Adhesion of probiotic bacteria cells onto Caco-2 cells in stirred fruit yogurt (A) and plain ice cream (B) made from goat milk. (Source: Ranadheera and others 2012; image reproduced with the permission of Elsevier).

Pandiyan and others (2012c) investigated the survivability of L. acidophilus NCDC 14 and its impact on the fecal microflora in the GIT tract of healthy human volunteers receiving synbiotic ice cream for $15 \mathrm{~d}$ (supplemented with FOS and whey proteins). The $\mathrm{pH}$ of the collected stool samples was significantly reduced throughout the ice cream ingestion period, reaching its lowest value on day 15 due to the formation of short-chain fatty acids by the colonic microbiota. Microbiological counts of the fecal samples after $15 \mathrm{~d}$ of ice cream consumption revealed a $1 \log$ CFU/g increase of L. acidophilus NCDC 14 in the gut epithelium. Finally, synbiotic ice cream consumption contributed to a reduced coliform load, attributed to the antagonistic adhesion between probiotic and pathogenic bacteria and the production of bacteriocins by L. acidophilus (Pandiyan and others 2012c). 


\section{Prebiotics}

\section{Technological and health aspects}

According to Roberfroid (2007), the term prebiotics is used to describe "selectively fermented ingredients resulting in specific changes both in the composition and activity of the GIT microbiota that confer benefits upon the host's well-being and health." Most prebiotics are primarily composed of oligosaccharides or more rarely may contain also polysaccharides, such as inulin (Saad and others 2013). Prebiotics offer a considerably broad spectrum of technofunctional, physiological, and nutritional aspects. Depending on the type, degree of polymerization (DP), and degree of branching (DB), prebiotics can exert significant texturizing properties, as they may retain water, interact with milk proteins, and form aggregates composed of hydrated microcrystals (Schaller-Povolny and Smith 2002; Meyer and others 2011a). Moreover, the ability of several prebiotic fibers including inulin, polydextrose, oligofructose, wheat dextrin to promote emulsion, and foam stability, to enhance viscosity, to induce gelation, and to mimic fat by reducing friction and imparting tongue lubrication during consumption has been reported (Fagan and others 2006; Meyer and others 2011b; Tárrega and others 2011; Soukoulis and Fisk in press). From a physiological point of view, the majority of the health claims for prebiotics are associated with their ability to modulate the colonic function by stimulating the growth of beneficial probiotic bacteria and suppressing the viability of pathogenic microorganisms such as Escherichia coli, Campylobacteri jejuni, Enterobacterium spp. Salmonella enteritidis, and others (Saad and others 2013). In addition, ingestion of prebiotics has been associated with immunomodulatory effects, prevention of colorectal cancer, regulation of serum cholesterol and triglyceride levels, improvement of mineral absorption and bone mineralization, reduced plasma glucose levels, and anti-inflammatory and anticariogenic properties (Saad and others 2013).

The prebiotic benefits related to health and technological aspects have been exploited in a series of food products, including milk and related beverages, semisolid dairy products, such as yogurt, custards, and spreads and aerated dairy desserts, also o/w and w/o emulsions such as salad dressings and mayonnaise, as well as bakery and pasta products, extruded foods, and breakfast cereals (Brennan and others 2004; Homayouni and others 2008a; Debon and others 2010; Tárrega and others 2011; Mantzouridou and others 2012). The synbiotic concept has often been adopted during ice cream prototyping, in order to combine fair product texture and stability with enhanced survival of probiotics during GIT digestion.

\section{Prebiotic functionality in ice cream systems}

Many food applications of prebiotics refer to synbiotic ice cream prototyping due to their ability to stimulate probiotic growth in the digestive tract, much research (Table $\underline{2}$ ) has been conducted for exploiting the technological properties of FOS, polydextrose, and resistant starch (as fat replacers for mouthfeel and as body enhancers, and also as cryoprotectants, thickeners, and foaming agents) (Karaca and others 2009; Soukoulis and others 2010b). Due to their lower molecular weight compared to polysaccharides, starch hydrolysates (such as maltodextrins), corn syrup solids, and prebiotics exert a fair impact on colligative food properties, depending on their DP and DB. More specifically, the presence of inulin and oligofructose in model sucrose solutions and ice cream systems at $1.6 \%$ to $4.8 \% \mathrm{w} / \mathrm{w}$ was 
reported to affect their thermophysical properties such as freezing point, unfrozen and freezable water content, and glass transition temperature (Soukoulis and others 2009; Soukoulis and others $\underline{2010 \mathrm{~b}}$ ).

Table 2. Overview of studies investigating the impact of dietary fiber (excluding polysaccharides) on the technological and sensory properties of ice cream

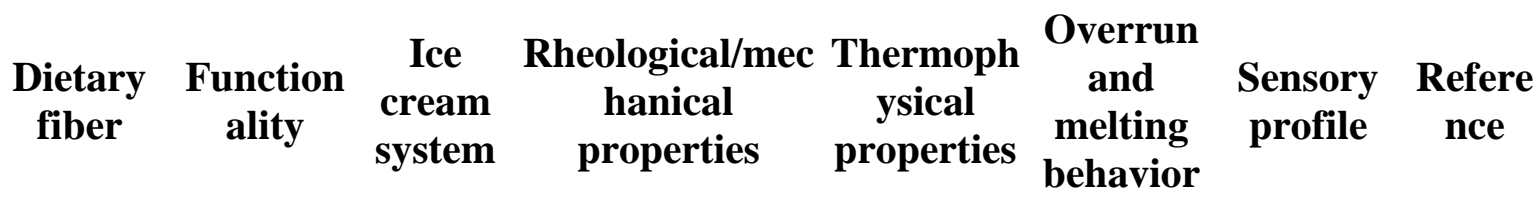

1. $\mathrm{Nd}=$ not determined (no data), $\mathrm{EMW}=$ effective molecular weight,$T_{f}=$ freezing point temperature, $T_{g}=$ glass transition temperature, $\mathrm{GI}=$ glycemic index.

\begin{tabular}{|c|c|c|c|c|c|c|c|}
\hline & & Low-fat & Increase of & & & $\begin{array}{l}\text { Improvem } \\
\text { ent of } \\
\text { smoothnes }\end{array}$ & \\
\hline Inulin & $\begin{array}{l}\text { Fat } \\
\text { replacer }\end{array}$ & $\begin{array}{l}(5 \%) \\
\text { yoghurt- } \\
\text { ice } \\
\text { cream } \\
5 \%, 7 \% \text {, } \\
\text { and } 9 \% \\
\text { inulin }\end{array}$ & $\begin{array}{l}\text { consistency } \\
\text { coefficient } \\
\text { Increased } \\
\text { stickiness } \\
\text { Firmness } \\
\text { reduction }\end{array}$ & $\mathrm{Nd}$ & $\begin{array}{l}\text { Improve } \\
\text { ment of } \\
\text { melting } \\
\text { resistance }\end{array}$ & $\begin{array}{l}\text { s } \\
\text { Reduction } \\
\text { of } \\
\text { grittiness, } \\
\text { iciness, } \\
\text { coarseness } \\
\text {, and } \\
\text { hardness }\end{array}$ & $\begin{array}{l}\text { El- } \\
\text { Nagar } \\
\text { and } \\
\text { others } \\
(\underline{2002)}\end{array}$ \\
\hline Inulin & $\begin{array}{l}\text { Fat } \\
\text { replacer }\end{array}$ & $\begin{array}{l}\text { Low-fat } \\
(3 \%) \text { ice } \\
\text { cream }\end{array}$ & $\mathrm{Nd}$ & $\mathrm{Nd}$ & $\mathrm{Nd}$ & $\begin{array}{l}\text { Impairmen } \\
t \text { of } \\
\text { perceived } \\
\text { texture No } \\
\text { impact on } \\
\text { flavor, } \\
\text { appearanc } \\
\text { e, and } \\
\text { color }\end{array}$ & $\begin{array}{l}\text { Devere } \\
\text { ux and } \\
\text { others } \\
(\underline{2003})\end{array}$ \\
\hline Inulin & $\begin{array}{l}\text { Fat } \\
\text { replacer }\end{array}$ & $\begin{array}{l}\text { Low-fat } \\
\text { ice } \\
\text { cream } \\
(0 \%, \\
2 \%, \text { and } \\
4 \% \text { fat }) \\
\text { with } 8 \% \text {, } \\
6 \% \text {, and } \\
4 \% \\
\text { inulin }\end{array}$ & $\begin{array}{l}\text { No impact on } \\
\text { hardness at } 4 \% \\
\text { and } 6 \% \text { inulin, } \\
\text { increased } \\
\text { hardness at } 8 \% \\
\text { Increase of } \\
\text { consistency } \\
\text { coefficient and } \\
\text { pseudoplasticity } \\
\text { at } 8 \%\end{array}$ & $\mathrm{Nd}$ & $\begin{array}{l}\text { Increased } \\
\text { overrun } \\
\text { at } 6 \% \text { and } \\
8 \% \text { inulin } \\
\text { Decrease } \\
\text { of } \\
\text { melting } \\
\text { rate at } 6 \% \\
\text { and } 8 \% \\
\text { inulin }\end{array}$ & $\begin{array}{l}\text { Flavor and } \\
\text { taste score } \\
\text { reduction } \\
(4 \% \text { and } \\
8 \%) \\
\text { Reduction } \\
\text { of body } \\
\text { and } \\
\text { texture } \\
\text { scores } \\
(8 \%)\end{array}$ & $\begin{array}{l}\text { Karaca } \\
\text { and } \\
\text { others } \\
(\underline{2009)})\end{array}$ \\
\hline Inulin & $\begin{array}{l}\text { Fat } \\
\text { replacer }\end{array}$ & $\begin{array}{l}\text { Low and } \\
\text { reduced } \\
\text { fat ice } \\
\text { cream } \\
\text { (3\% and }\end{array}$ & $\begin{array}{l}\text { Reduction of } \\
\text { consistency } \\
\text { coefficient, } \\
\text { apparent } \\
\text { viscosity, and }\end{array}$ & $\mathrm{Nd}$ & $\begin{array}{l}\text { Overrun } \\
\text { reduction } \\
\text { by fat } \\
\text { lowering } \\
\text { Improve }\end{array}$ & $\mathrm{Nd}$ & $\begin{array}{l}\text { Akalin } \\
\text { and } \\
\text { others } \\
(\underline{2008)})\end{array}$ \\
\hline
\end{tabular}




\begin{tabular}{|c|c|c|c|c|c|c|c|}
\hline $\begin{array}{c}\text { Dietary } \\
\text { fiber }\end{array}$ & $\begin{array}{c}\text { Function } \\
\text { ality }\end{array}$ & \begin{tabular}{l}
\multicolumn{1}{c}{$\begin{array}{c}\text { Ice } \\
\text { cream } \\
\text { system }\end{array}$} \\
$6 \%)$ \\
with $4 \%$ \\
inulin
\end{tabular} & $\begin{array}{c}\text { Rheological/mec } \\
\text { hanical } \\
\text { properties }\end{array}$ & $\begin{array}{c}\text { Thermoph } \\
\text { ysical } \\
\text { properties }\end{array}$ & $\begin{array}{l}\begin{array}{c}\text { Overrun } \\
\text { and } \\
\text { melting }\end{array} \\
\text { behavior } \\
\text { ment of } \\
\text { melting } \\
\text { resistance }\end{array}$ & $\begin{array}{c}\text { Sensory } \\
\text { profile }\end{array}$ & $\begin{array}{c}\text { Refere } \\
\text { nce }\end{array}$ \\
\hline Inulin & $\begin{array}{l}\text { Fat } \\
\text { replacer }\end{array}$ & $\begin{array}{l}\text { Low } \\
(1.6 \%) \\
\text { and } \\
\text { nonfat } \\
\text { ice } \\
\text { cream } \\
(5.7 \% \\
\text { and } \\
6.2 \% \\
\text { inulin) }\end{array}$ & $\begin{array}{l}\text { Viscosity } \\
\text { enhancement }\end{array}$ & $\mathrm{Nd}$ & $\begin{array}{l}\text { Decrease } \\
\text { of } \\
\text { overrun } \\
\text { No } \\
\text { impact on } \\
\text { melting } \\
\text { rate } \\
\text { Improve } \\
\text { ment of } \\
\text { shape } \\
\text { retention }\end{array}$ & $\begin{array}{l}\text { No impact } \\
\text { on } \\
\text { appearanc } \\
\text { e, color, } \\
\text { and flavor } \\
\text { attributes } \\
\text { Improvem } \\
\text { ent of } \\
\text { body and } \\
\text { texture }\end{array}$ & $\begin{array}{l}\text { Aykan } \\
\text { and } \\
\text { others } \\
(\underline{2008})\end{array}$ \\
\hline Inulin & $\begin{array}{l}\text { Corn } \\
\text { syrup } \\
\text { solids } \\
\text { (CSS) } \\
\text { replacer }\end{array}$ & $\begin{array}{l}\text { Reduced } \\
\text { fat ice } \\
\text { cream } \\
\text { CSS } \\
(6.7 \%) \\
\text { were } \\
\text { partially } \\
(50 \%) \text { or } \\
\text { fully } \\
\text { replaced } \\
\text { by inulin }\end{array}$ & $\mathrm{Nd}$ & $\mathrm{Nd}$ & $\mathrm{Nd}$ & $\begin{array}{l}\text { Reduced } \\
\text { iciness } \\
\text { and } \\
\text { increased } \\
\text { chewiness } \\
\text { in fresh } \\
\text { and } \\
\text { thermally } \\
\text { abused } \\
\text { samples } \\
\text { Reduction } \\
\text { of flavor } \\
\text { and } \\
\text { sweetness } \\
\text { intensity } \\
\text { of fresh } \\
\text { and heat } \\
\text { shocked } \\
\text { samples }\end{array}$ & $\begin{array}{l}\text { Schalle } \\
\text { r- } \\
\text { Povoln } \\
\text { y and } \\
\text { Smith } \\
(\underline{1999)}\end{array}$ \\
\hline Inulin & $\begin{array}{l}\text { Sugar } \\
\text { replacer }\end{array}$ & $\begin{array}{l}\text { Full-fat } \\
\text { ice } \\
\text { cream } \\
10 \% \text { and } \\
30 \% \\
\text { sucrose } \\
\text { replacem } \\
\text { ent }\end{array}$ & $\begin{array}{l}\text { Increase of } \\
\text { consistency } \\
\text { coefficient, } \\
\text { apparent } \\
\text { viscosity (at } 50 \\
\mathrm{~s}^{-1} \text { ), and } \\
\text { pseudoplasticity } \\
\text { Increase of } \\
\text { instrumental } \\
\text { hardness }\end{array}$ & $\begin{array}{l}\text { Elevation } \\
\text { of } T_{g}, \\
\text { increase of } \\
\text { EMW, } \\
\text { nonfreezabl } \\
\text { e water } \\
\text { amount, } \\
\text { and ice } \\
\text { crystals } \\
\text { homogeneit } \\
\text { y }\end{array}$ & $\begin{array}{l}\text { Improved } \\
\text { overrun } \\
\text { at } 30 \% \text { of } \\
\text { sucrose } \\
\text { replacem } \\
\text { ent } \\
\text { Reductio } \\
\text { n of air } \\
\text { cells } \\
\text { mean size } \\
\text { Improve } \\
\text { ment of }\end{array}$ & $\begin{array}{l}\text { Reduction } \\
\text { of } \\
\text { perceived } \\
\text { vanilla } \\
\text { flavor, } \\
\text { iciness, } \\
\text { coarseness } \\
\text { brittleness, } \\
\text { wateriness } \\
\text { Increase } \\
\text { of }\end{array}$ & $\begin{array}{l}\text { Soukou } \\
\text { lis and } \\
\text { others } \\
(2010 \mathrm{a} \\
)\end{array}$ \\
\hline
\end{tabular}




\begin{tabular}{|c|c|c|c|c|c|c|c|}
\hline $\begin{array}{l}\text { Dietary } \\
\text { fiber }\end{array}$ & $\begin{array}{c}\text { Function } \\
\text { ality }\end{array}$ & $\begin{array}{c}\text { Ice } \\
\text { cream } \\
\text { system }\end{array}$ & $\begin{array}{c}\text { Rheological/mec } \\
\text { hanical } \\
\text { properties }\end{array}$ & $\begin{array}{l}\text { Thermoph } \\
\text { ysical } \\
\text { properties }\end{array}$ & $\begin{array}{l}\text { Overrun } \\
\text { and } \\
\text { melting } \\
\text { behavior }\end{array}$ & $\begin{array}{c}\text { Sensory } \\
\text { profile }\end{array}$ & $\begin{array}{c}\text { Refere } \\
\text { nce }\end{array}$ \\
\hline & & & & & $\begin{array}{l}\text { melting } \\
\text { resistance }\end{array}$ & $\begin{array}{l}\text { hardness, } \\
\text { gummines } \\
\text { s, and } \\
\text { creamines } \\
\text { s }\end{array}$ & \\
\hline Inulin & $\begin{array}{l}\text { Dietary } \\
\text { fiber } \\
\text { fortificati } \\
\text { on }\end{array}$ & $\begin{array}{l}\text { Full-fat } \\
\text { ice } \\
\text { cream } \\
\text { mixes } \\
\text { with } 2 \% \\
\text { or } 4 \% \\
\text { inulin }\end{array}$ & $\begin{array}{l}\text { Viscosity and } \\
\text { consistency } \\
\text { coefficient } \\
\text { enhancement at } \\
4 \% \text { Increase of } \\
\text { shear thinning } \\
\text { behavior at } 4 \% \\
\text { Increased } \\
\text { hardness at 5\% } \\
\text { and } 10 \%\end{array}$ & $\begin{array}{l}\text { Elevation } \\
\text { of } T_{f} \text { and } \\
\text { EMW at } \\
4 \% \\
\text { Elevation } \\
\text { of } T_{g} \text { at } \\
\text { both } \\
\text { concentrati } \\
\text { ons }\end{array}$ & $\mathrm{Nd}$ & $\mathrm{Nd}$ & $\begin{array}{l}\text { Soukou } \\
\text { lis and } \\
\text { others } \\
(\underline{2009)}\end{array}$ \\
\hline $\begin{array}{l}\text { Oligofruct } \\
\text { ose }\end{array}$ & $\begin{array}{l}\text { Sugar } \\
\text { replacem } \\
\text { ent }\end{array}$ & $\begin{array}{l}\text { Full-fat } \\
\text { ice } \\
\text { cream } \\
10 \% \text { and } \\
30 \% \\
\text { sucrose } \\
\text { replacem } \\
\text { ent by } \\
\text { oligofruc } \\
\text { tose }\end{array}$ & $\begin{array}{l}\text { Minor impact on } \\
\text { apparent } \\
\text { viscosity }\left(50 \mathrm{~s}^{-1}\right) \\
\text { and } \\
\text { pseudoplasticity } \\
\text { Enhancement of } \\
\text { consistency } \\
\text { coefficient }\end{array}$ & $\begin{array}{l}\text { Elevation } \\
\text { of } T_{g}, \\
\text { increase of } \\
\text { EMW, } \\
\text { nonfreezabl } \\
\text { e water } \\
\text { amount, } \\
\text { and ice } \\
\text { crystal } \\
\text { homogeneit } \\
\text { y }\end{array}$ & $\begin{array}{l}\text { Improved } \\
\text { overrun } \\
\text { at } 30 \% \text { of } \\
\text { sucrose } \\
\text { replacem } \\
\text { ent } \\
\text { Reductio } \\
\text { n of air } \\
\text { cell mean } \\
\text { size } \\
\text { Improve } \\
\text { ment of } \\
\text { melting } \\
\text { resistance }\end{array}$ & $\begin{array}{l}\text { Reduction } \\
\text { of } \\
\text { perceived } \\
\text { iciness, } \\
\text { coarseness } \\
\text { brittleness, } \\
\text { wateriness } \\
\text { Increase } \\
\text { of } \\
\text { hardness, } \\
\text { gummines } \\
\text { s, and } \\
\text { creamines } \\
\text { s More } \\
\text { intense } \\
\text { vanilla } \\
\text { flavor and } \\
\text { sweet taste }\end{array}$ & $\begin{array}{l}\text { Soukou } \\
\text { lis and } \\
\text { others } \\
(\underline{2010 \mathrm{a}} \\
\text { ) }\end{array}$ \\
\hline \multicolumn{8}{|l|}{$\begin{array}{l}\text { Oligofruct } \\
\text { ose }\end{array}$} \\
\hline $\begin{array}{l}\text { Polydextro } \\
\text { se }\end{array}$ & $\begin{array}{l}\text { Fat } \\
\text { replacer }\end{array}$ & $\begin{array}{l}\text { Low-fat } \\
(4 \%) \text { ice } \\
\text { cream }\end{array}$ & $\mathrm{Nd}$ & $\mathrm{Nd}$ & $\mathrm{Nd}$ & $\begin{array}{l}\text { Lower } \\
\text { coldness } \\
\text { intensity } \\
\text { No impact } \\
\text { on } \\
\text { creamines } \\
\text { s, } \\
\text { mouthcoat } \\
\text { ing, and }\end{array}$ & $\begin{array}{l}\text { Liou } \\
\text { and } \\
\text { Grün } \\
(\underline{2007)}\end{array}$ \\
\hline
\end{tabular}




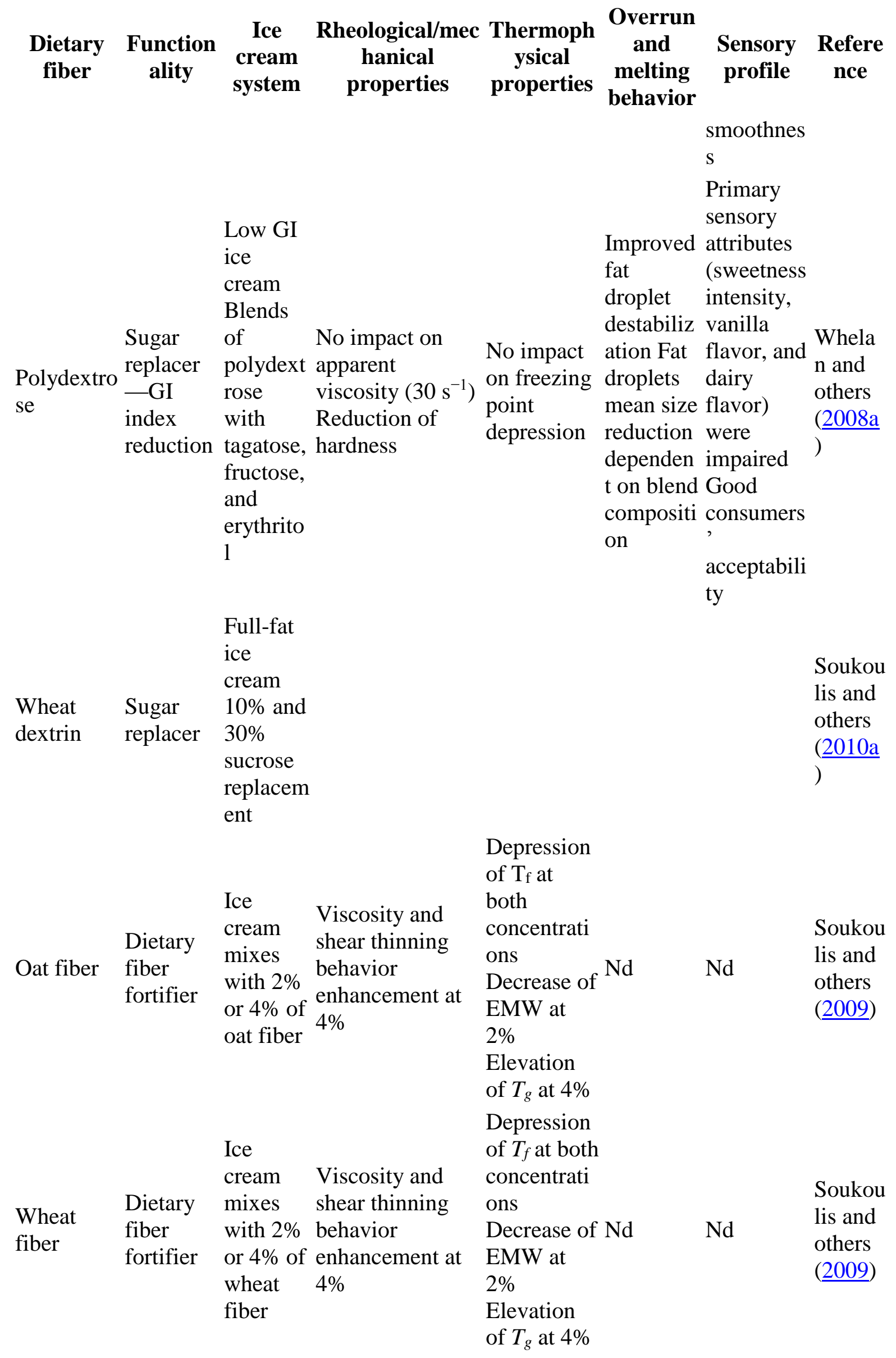




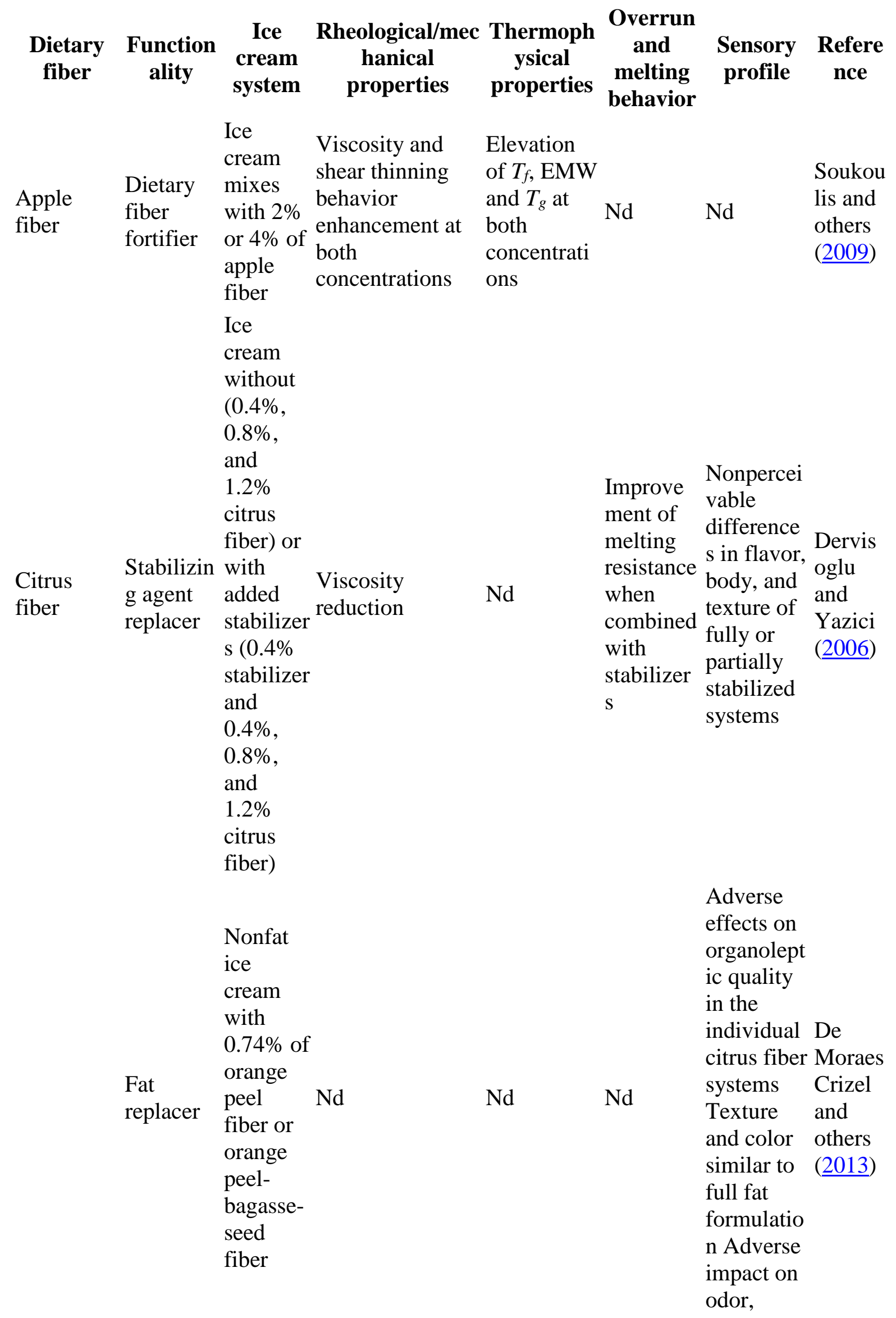




$\begin{array}{cccccccc}\text { Dietary } & \text { Function } & \begin{array}{c}\text { Ice } \\ \text { cream }\end{array} & \begin{array}{c}\text { Rheological/mec } \\ \text { hanical }\end{array} & \begin{array}{c}\text { Thermoph } \\ \text { ysical }\end{array} & \begin{array}{c}\text { Overrun } \\ \text { and } \\ \text { melting }\end{array} & \begin{array}{c}\text { Sensory } \\ \text { profile }\end{array} & \begin{array}{c}\text { Refere } \\ \text { nce }\end{array} \\ & \text { ality } & \begin{array}{c}\text { system } \\ \text { properties }\end{array} & \text { properties } & \begin{array}{c}\text { meling } \\ \text { behavior }\end{array} & & & \end{array}$

\begin{tabular}{lllll} 
& & & & \multicolumn{1}{c}{$\begin{array}{l}\text { flavor, and } \\
\text { aftertaste } \\
\text { No impact } \\
\text { on }\end{array}$} \\
appearanc \\
Soluble
\end{tabular}

The increase of carbon chain length and the branching degree appear to be related to the impact on freezing point temperature (FPT) and glass transition phenomena, with the higher DP inulin exhibiting a better cryoprotective potential compared to oligofructose (Soukoulis and others 2010a). In addition, long-chain inulin as a replacer of corn syrup solids (42 DE) led to significant reduction of mean ice crystal size and FPT depression of low-fat ice cream, supporting its cryoprotective role (Schaller-Povolny and Smith 2001). Although the mechanisms of the cryoprotective activity of FOS in ice creams are not fully explored, it has been attributed to synergistic effects in retaining and binding water, to reduced amounts of freezable water, to increased microviscosity, to controled water diffusion in the freezeconcentrated serum phase, and to ice crystal size distribution (Schaller-Povolny and Smith 2001; Soukoulis and others 2009). Polydextrose has been used extensively as a cryoprotective bulking agent in low-fat or fat-free ice cream formulations due to its ability to reduce the FPT of ice cream mixes compared to sucrose (Baer and Baldwin 1984; Alvarez and others 2005; Whelan and others 2008b). Moreover, adding polydextrose to ice cream can increase the uniformity of ice crystals, leading to enhanced creaminess and mouthfeel perception (Alvarez and others 2005).

The ability of FOS to improve the viscosity of dairy o/w emulsions (for example, dairy desserts and ice creams) is well established (Schaller-Povolny and Smith 2001; El-Nagar and others 2002; Karaca and others 2009; Debon and others 2010; Isik and others 2011; Tárrega and others 2011). Parameters such as DP, DB, and FOS concentration have been reported to impact the viscosity of semisolid dairy dessert systems (Tárrega and others 2011). Apart from the contribution of viscosity to the freezing-whipping process (a minimum viscosity is required for inducing fat destabilization and air cell stabilization), viscosity has been reported to interrelate with texture perception (creaminess, wateriness, mouth coating, tongue lubrication, friction, and roughness) during consumption (Soukoulis and others 2008; González-Tomás and others 2009; Soukoulis and others 2010b; Bayarri and others 2011).

Inulin and oligofructose have also been employed in ice creams as sugar replacers (for sucrose or corn syrup solids), exerting a significant enhancement of macroviscosity. This is likely not only due to an increase of total solids, but also due to the ability of inulin to hydrate 
and bind water (Schaller-Povolny and Smith 2001; El-Nagar and others 2002; Soukoulis and others 2009; Soukoulis and others 2010b). Karaca and others (2009) deduced that polydextrose did not impart viscous characteristics to regular, low-fat, and nonfat ice creams, while modified starch and inulin induced a prominent increase of macroviscosity. Contrary to other studies, the authors also observed that the thickening ability of inulin was strongly dependent on the milk fat content of ice cream, with nonfat formulations promoting the highest viscosity. In line with the former observations, no significant effects of adding polydextrose on the rheological profile of aged ice cream were reported by Whelan and others (2008a), Alvarez and others (2005), and Roland and others (1999). The feasibility of microfluidized and heat-treated resistant starch as thickening agents in ice cream was studied by Augustin and others (2007). The investigators reported a pronounced viscosity increase $(7.6 \mathrm{cP})$ in the presence of resistant starch compared to native high-amylose starch and noadded starch (2.4 and $1.3 \mathrm{cP}$, respectively).

Prebiotics may also facilitate air incorporation and foam stabilization by increasing the viscosity of the aqueous phase (by increasing solute concentration or gelation) surrounding the air cell interface, raising the physical barrier against air cell destabilization via Ostwald ripening (Franck 2002; Herceg and others 2007). Although there is a lack of studies regarding the functionality of prebiotics such as FOS or resistant starch to act as colloids, most ice cream studies demonstrated that inulin, oligofructose, or resistant starch substantially enhanced air incorporation (overrun) and related properties such as melting resistance and shape retention (El-Nagar and others 2002; Augustin and others 2007; Akalin and Erişir 2008; Aykan and others 2008; Karaca and others 2009; Soukoulis and others 2010b).

Increasing the fat and sugar contents of frozen dairy desserts is further associated with superior texture and flavor characteristics such as enhanced mouth coating, tongue lubrication, creaminess, flavor release, reduced iciness, coarseness, friction, and wateriness (Koeferli and others 1996; Prindiville and others 1999). Ice cream reformulation on a customized dietary basis, for example, low-fat or low-sugar content, limited use of food additives, and so on, is challenging as in most cases texture, flavor and taste deterioration is experienced. The ability of many prebiotics to mimic fat technofunctionality has been extensively exploited in the manufacture of health-related food products such as low-fat or nonfat and low GI bakery and dairy food items (Franck 2002). Especially inulin has a dominating role on the development of low-fat and/or low-sugar ice cream due to the ability of its native or long-chain-like structure to create gels of various firmness via microcrystal aggregation and agglomeration (Meyer and others 2011a). In general, inulin has been reported to reduce iciness and to enhance chewiness of thermally abused ice creams via its ability to impact colligative properties. Similarly, partial substitution of sucrose by inulin or oligofructose improved texture and sensory parameters such as iciness, coarseness, wateriness, and brittleness. The ability of FOS to change ice crystallization/recrystallization processes via elevating the freezing point and reducing unfrozen water mobility was suggested as governing factors for these effects (Soukoulis and others 2010b).

\section{Dietary Fiber}

\section{Definitions, technological, and physiological aspects}

According to the Codex Alimentarius Commission, DF includes naturally occurring and enzymatically, chemically, or physically isolated and synthetic, edible carbohydrate polymers 
with 10 or more monomeric units, which are not hydrolyzed by endogenous enzymes in the human small intestine (Codex 2009). DF can be further classified into soluble and insoluble DF, high-molecular-weight (polysaccharides), and low-molecular-weight (oligosaccharides) DF (Westenbrink and others 2013), as well as into fermentable (by colonic bacteria) and nonfermentable fiber such as cellulose and lignin. While prebiotics are also fermentable DF, the focus in this section is on fibers that have not shown benefits on the colonic microbiota.

DF in food products exerts a wide range of technological aspects, including water-holding (WHC), water-swelling (WSC), and water-retention (WRC) capacity, influencing water solubility, oil holding capacity (OHC), viscosity, texture and texture stability, gel-forming capacity, and even antioxidant capacity (Elleuch and others 2011). Pectins, gums, and mucilages are generally characterized as water soluble, while cellulose, most types of hemicellulose, and lignin comprise the insoluble fraction of DF (Chawla and Patil 2010). Both water solubility and hydration properties are influenced by the fiber structure, presence of hydrophilic functions such as $-\mathrm{OH},-\mathrm{COOH}$ or $-\mathrm{SO}_{4}{ }^{2-}$, temperature, and ionic strength (Elleuch and others 2011). On the other hand, viscosity is mainly affected by the type and concentration of soluble DF, while the impact of the insoluble DF fraction on the rheological behavior of aqueous systems is rather limited. In addition, depending on concentration (below or above the critical concentration $\left.c^{*}\right), \mathrm{pH}$, ionic strength, and temperature, soluble DF macromolecular conformation can vary from the dilute to the overlapping (entangled) state (Foster and Wolf 2011). Many random-coil soluble DFs such as alginates, carrageenans, gellan, or locust bean gum have the ability to form cross-linked gel networks that can be $\mathrm{pH}$ or temperature-reversible. The latter has found many applications in the structuring and texturizing of semisolid and solid food systems.

DF incorporation into food products does not only aim to customize structure and texture, but also to provide specific dietary and physiological benefits. The physiological role of DFs is mainly attributed to their ability to enhance water binding, and viscosity/gel formation in the GIT tract, thus increasing fecal bulk, promoting peristalsis, and modifying colloidal elements of the food matrix, their biochemical aspects, and their impact on the large bowel microbiota diversity and metabolic activity (Brownlee 2011). Adoption of a fiber (especially insoluble)rich diet has been reported to be associated with reduced gut transit time, facilitating frequent defecation. Animal studies have also shown that the ingestion of fermentable DF, such as FOS or gum arabic, can affect the T-cell composition of gut-associated lymphoid tissue (GALT) compared to nonfermentable DF. On the other hand, it has been shown that both insoluble and soluble DF fractions can exert a protective effect on the colonic mucus barrier (Brownlee 2011). Ingestion of fair amounts of nonfermentable DF (about $30 \mathrm{~g} / \mathrm{d}$ ) is known to contribute to the balance of the colonic microbiota. Generally, the presence of nonfermentable DF in the digesta favors the growth of the native microbiota such as Bifidobacteria or Lactobacilli, resulting in the formation of short-chain fatty acids, in particularly butyric acid. The latter is believed to play an important role in modulating the health of the colonic epithelium (Topping and Clifton 2001), which is likely to be due to the anti-inflammatory properties of short-chain fatty acids (Vinolo and others 2011).

Additional health benefits conferred by consuming DF-rich food include lowered blood cholesterol levels and reduced postprandial serum glucose response, reducing the risk of developing obesity, cardiovascular disease, and type 2 diabetes (Hodge and others 2004; Brownlee 2011; Mudgil and Barak 2013). It is generally considered that lowering total and low-density lipoprotein cholesterol (LDL-C) takes place via altering cholesterol (re)absorption, hepatic metabolism, and plasma clearance of lipoproteins (Mudgil and Barak 
2013). DFs that promote viscosity enhancement or gelation (for example, oat- $\beta$-glucans, pectins, and guar gum) have been reported to constitute superior modulators of blood lipids (Mudgil and Barak 2013). In a recent randomized cross-over clinical study, it has been shown that the inclusion of high-viscosity fiber in the diet was able to reduce the plasma LDL-C by $9 \%$ and $17 \%$ compared to medium or low-viscosity DF-rich diets, respectively (Vuksan and others 2011). In addition, it has been reported that the ingestion of highly viscous DF was strongly correlated with reduced postprandial plasma glucose levels (Chutkan and others 2012). Several viscosity-related mechanisms, such as increased chime viscosity, a decrease of the GI of ingested food, reduced glucose absorption, and reduced starch degradation in the small intestine in conjunction with improved hormonal responses to nutrients, may explain the impact of highly viscous DF on postprandial plasma glucose response (Chutkan and others 2012).

Despite these physiological aspects, polysaccharides are used in ice cream in rather limited amounts, usually not exceeding $0.5 \%$ to $0.6 \% \mathrm{w} / \mathrm{w}$, and thus other food products can be considered better sources of DF. Except for prebiotics (FOS, inulin, resistant starch, and polydextrose) that can be added in remarkably higher amounts (up to $4 \% \mathrm{w} / \mathrm{w}$ ) due to their limited thickening effect, attempting to further increase the amount of soluble fiber will lead to undesirable effects such as overstabilization and poor processing properties and handling. Chen and others (2010) used water-soluble soybean polysaccharide (SSPS) as an alternative to increase DF (from $1 \%$ to $4 \% \mathrm{w} / \mathrm{w}$ ) in dairy desserts, including low-fat ice cream. The increased SSPS concentration induced a significant viscosity increase compared to conventionally stabilized analogs, although the changes in hardness and melting rates were rather minor. Mapping the consumers' willingness to purchase DF-rich ice cream formulations revealed a "moderate likely" intent to consume the SSPS-fortified products containing $2 \% \mathrm{w} / \mathrm{w}$ of SSPS, one of the highest levels for nonfat ice creams (Chen and others $\underline{2010})$.

\section{Enrichment of ice cream with insoluble fiber}

Enrichment of ice cream with insoluble fiber has been investigated in a series of studies to attempt improving its rheological properties, storage stability, and melting resistance, but also in order to provide health benefits (Dervisoglu 2006; Dervisoglu and Yazici 2006; Soukoulis and others 2009; de Moraes Crizel and others 2013).

The addition of DF (oat, wheat, and apple) with a high content of insoluble matter (45\% to $93 \% \mathrm{w} / \mathrm{w}$ ) into ice cream enhanced macroviscosity and induced a significant elevation of the glass transition and melting point of the frozen systems (Soukoulis and others 2009). The cryoprotective effects of oat and wheat fiber were attributed to their ability to retain high amounts of water, leading to hindered mobility of the water molecules in the freezeconcentrated serum. On the other hand, the presence of pectin, for example, in the case of apple fiber, can also contribute to cryopreservation of ice cream by controlling water molecule mobility in the unfrozen aqueous phase due to its thermodynamic incompatibility with the proteins present, exerting phase separation (Soukoulis and others 2009).

In a recent study, de Moreas Crizel and others (2013) have investigated the use of orange peel and orange peel-pulp-seed-isolated fiber (rich in soluble and insoluble fiber and total phenolics) as a potential fat replacer. The authors reported that incorporating both orange fiber types exerted a fat-mimetic function, allowing a $70 \%$ fat reduction (from 18 to $5 \mathrm{~g} / 100 \mathrm{~g}$ in the finished product), with no significant modification of color, odor, and texture despite a 
slight impairment of the flavor and overall acceptability of the low-fat formulation. The study by de Moreas Crizel and others (2013) showed that the consumers' purchase intent did not decrease dramatically toward low-fat formulations (74\% compared to $94 \%$ for regular ice cream), which appeared to be associated with a growing number of health aware and functional-food-conscious consumers.

In a series of studies, Dervisoglu (2006) evaluated the feasibility of using food industry byproducts rich in insoluble DF, such as citrus fiber, hazelnut flour, and hazelnut kernel skin. Citrus fiber as an individual stabilizing agent $(0.4 \%$ to $1.2 \% \mathrm{w} / \mathrm{w})$ did not significantly impact viscosity development and air incorporation. However, increased citrus fiber content was associated with a remarkable improvement of ice cream melting resistance (Dervisoglu and Yazici 2006). Fortification of nonfat ice cream with hazelnut flour (up to $3.0 \% \mathrm{w} / \mathrm{w}$ ) significantly improved overrun, viscosity, and melting resistance of ice creams without impairing appearance, flavor, body, and texture. On the other hand, hazelnut kernel skins, apart from its good foam formation and stabilizing ability, induced a significant deterioration of textural and sensory properties of the finished products (Dervisoglu 2006).

\section{Low Glycemic Index Sweeteners}

\section{Overview}

The GI concept of foods has been introduced in order to provide a quantifiable marker of the response of a specified amount of ingested carbohydrate compared to a standard food reference, for example, glucose or white wheat bread (Martin and others 2008). A high-GI food is expected to cause a faster and higher rise of blood glucose levels than a food with a low GI, given the same carbohydrate content. Factors such as DF content, the nature of starch and monosaccharide components, viscosity, particle size, food processing, ripeness, storage practices, the presence of alpha-amylase inhibitors, nutrient-starch interactions, and so on, have been reported to influence the GI (Agustin and others 2002). Lowering the GI of food products has been associated with several health benefits, including decreased incidence of obesity, reduction of diabetes type 2 and coronary heart disease risk, and the prevention of hyperinsulinemia/insulin resistance-induced cancer such as colorectal, breast, and prostate cancer (Agustin and others 2002). Popovich and others (1996), studying the GI of several common food products, reported that a typical vanilla ice cream can be considered as a lowGI (42 \pm 5 using dextrose as a reference) food. In a later study, Foster-Powell and others (2002) reported that the GI of ice cream depended on its formulation, with gelato and chocolate-frozen dairy desserts being characterized by the highest GI values, namely, 57 to 80 .

Over the last decade, a constant increase of diabesity (the joint occurrence of diabetes type 2 and obesity) incidence has been recorded; the prevalence of diabesity from 2000 to 2030 is expected to rise from 171 to 366 million people worldwide (Ben-Avraham and others 2009). This has also impacted the ice cream industry toward producing products of reduced GI, targeting mainly consumers suffering from diabesity.

Reduction of GI in ice cream cannot be carried out by simply removing sucrose, as the resulting product would lack adequate scoopability, mouthfeel, and sweetness (Marshall and others 2003). Rather, the partial or total substitution of high-GI sweeteners (sucrose, dextrose, and corn syrup solids), by low-GI sweeteners (polyols, fructose, and the noncaloric 
sweeteners such as aspartame, cyclamate, or saccharin) is common practice to reduce the GI (Abril and others 1982; Goff and Jordan 1984; Özdemir and others 2003; Maia and others 2008; Ozdemir and others 2008; Whelan and others 2008a, 2008b; Soukoulis and others 2010a; Soukoulis and Tzia 2010). In most cases, the GI reduction is accompanied by a significant change of the colligative properties of ice cream (FPT, fraction of frozen water, and glass transition temperature), as well as growth and morphological aspects of ice crystals impacting texture and storage stability (Hagiwara and Hartel 1996; Miller-Livney and Hartel 1997; Ablett and others 2002; Muse and Hartel 2004).

\section{Caloric sweeteners}

Fructose has a GI of 14 to 23, is naturally occurring in fruits and vegetables, and is of higher sweetening power (1.2 to 1.7 times) than sucrose (O'Brien-Nabors 2001). In addition, its metabolism is insulin-independent. Fructose can be incorporated into ice cream either in pure crystalline form or as corn starch hydrolyzates that is high fructose corn syrups (HFCSs). However, it should be noted that the GI of the latter is pronouncedly higher than that of fruitand vegetable-derived fructose, due to the presence of additional sugars. Studies on healthy and diabetic (insulin- and noninsulin-dependent) subjects have demonstrated that fructose intake produces a lower postprandial rise of glucose and insulin (Bantle 2005). Moreover, the passive absorption of fructose from the intestine and its high postprandial thermogenic response and hepatic oxidation has been reported to be associated with improved satiety (Melanson and others 2008). On the other hand, recent studies have shown that adopting diets high in fructose may lead to obesity, possibly due to inducing a rather lipogenic response. Furthermore, the strong impact of fructose on the colligative properties of ice cream may impair its texture (development of iciness and coarseness) and storage stability due to acceleration of ice recrystallization phenomena. For this reason, fructose is only used as a cocomponent of the bulk sweetening agents for improving mouthfeel, scoopability, and enhancing sweetness. Abril and others (1982) have demonstrated that combining fructose with low DE maltodextrin and xylitol can impart texturizing properties and increase consumer acceptability. Partial substitution of sucrose by fructose has been reported to depress the freezing point and glass transition temperature of ice creams, reducing the instrumental hardness and melting resistance and increasing overrun (Soukoulis and others 2010b; Silva Junior and Lannes 2011). Despite the adverse impact of fructose on icy, coarse, and watery mouthfeel, it was shown that sucrose substitution by fructose (up to $30 \% \mathrm{w} / \mathrm{w}$ ) can significantly promote flavor release (Soukoulis and others $\underline{2010 \mathrm{~b}}$ ).

Polyols (polyhydric alcohols) are poly-hydroxyl compounds originating from their parent reducing sugars (O'Brien-Nabors 2001). Polyols are hygroscopic, heat- and acid-stable compounds that do not undergo Maillard reactions. They have a strong impact on colligative properties of aqueous solutions (many of them are widely used for cryopreservation of biological tissues) and they are characterized by a lower GI and lower to equal sweetening power (0.3 to 1.0) compared to sucrose (O'Brien-Nabors 2001). In addition, depending on the polyol type, several physiological features have been described, namely, low caloric load, anticariogenic properties, and low absorption in the digestive tract. On the other hand, excessive use of polyols (>10 to $20 \mathrm{~g}$ for mannitol and xylitol, $23 \mathrm{~g}$ for sorbitol, and $29 \mathrm{~g}$ for isomalt) may lead to laxative effects and impair flavor and taste characteristics, resulting in cooling effects, and formation of unnatural or metallic off-flavors.

Polyols such as maltitol, sorbitol, xylitol, mannitol, and isomalt have been implemented in the manufacture of low or nonsugar ice creams (Özdemir and others 2003; Bordi and others 
2004; Whelan and others 2008a; Soukoulis and others 2010a). In a series of studies, maltitol has been identified as a very efficient ingredient for lowering the GI and the sugar content of ice cream without compromising texture, flavor, or taste. Özdemir and others (2003) developed an ice cream product suitable for diabetic patients based exclusively on sorbitol or maltitol. The authors demonstrated that blood glucose concentration was reduced from 381 $\mathrm{mg} / 100 \mathrm{~g}$ (sucrose-based product) to 104 and $108 \mathrm{mg} / 100 \mathrm{~g}$ in the case of sorbitol- or maltitol-based analogs, respectively.

Carlson and others (2011) developed a method to produce LGSs by the reaction of sucrose with an acceptor (sugars or sugar alcohols having free hydroxyl groups at 1 or more carbon position numbers, namely, 2, 3, or 6). The reaction was catalyzed by glucan-sucrase and is based on the glucose transfer from sucrose to the acceptor, releasing fructose and glucooligosaccharides. The resulting product has a GI lower than that of sucrose (17 to 38) and technofunctional properties similar to those of corn syrups. The incorporation of LGS in sugar-free ice cream allowed the efficient reduction of their GI without modifying significantly their colligative properties and mouthfeel.

Johannsen and others (2007) patented a method for producing low-GI ice cream formulations based on the technofunctional synergism of polyols, nondigestible nonstarch complex carbohydrates, whey proteins, and starch derivatives. The inventors reported that the developed sugar-free ice creams exerted a GI ranging from 20 to 37 and were organoleptically acceptable. Nonetheless, products were firmer and less sweet than conventional ice creams. In the same study, it was reported that the increase of lactose in ice cream does not only increase the occurrence of malabsorption-related disorders, but that it could also lead to an increased GI of the finished product.

In a similar approach, Anfinsen and Tungland (2006) demonstrated that incorporating a blend of low-molecular weight (90 to $190 \mathrm{Da}$ ) low-digestible sweeteners (mannitol, maltitol, sorbitol, lactitol, erythritol, xylitol, tagatose, fructose, and others) and fermentable fibers (inulin, oligofructose, resistant starch, and so on) can promote ice cream functionality and reduce its GI value without altering its colligative and organoleptic properties. According to the investigators, the low-digestible sweeteners tended to retain the original freezing point depression (FPD), sweetness, flavor intensity, texture, tongue lubrication, and mouthcoating. The need to control the FPD upon GI reduction in ice cream has also been highlighted by Whelan and others $(\underline{2008 \mathrm{~b}})$ who investigated the impact of different low-GI sweetening blends (polyols and prebiotics) on freezing characteristics, viscosity, overrun, and texture of ice cream. The authors deduced that reformulation of low GI frozen dairy desserts should target and match the FPD curves of the low-GI systems to those of conventional ice cream.

\section{Noncaloric sweeteners}

Over the last several years, a strong interest in plant-derived noncaloric sweeteners has arisen sweet diterpenoid glycosides such as ent-kaurene glycosides, sweet triterpenoid glycosides such as cycloartane, oleanane, and curcubitane glycosides, and sweet-tasting proteins or sweetness-inducing proteins (including thaumatin, monellin, and mabillin) did arise (Faus and Sisniega 2004; Pawar and others 2013). These noncaloric sweeteners are of negligible caloric content, but often possess sweetness many times higher than that of glucose. Therefore, small amounts in the final product often suffice. The introduction of sweet glycosides such as stevioside, rebaudioside (Stevia rebaudiana leaf extracts), and mogroside V (Siraitia grosvenorii fruit extracts) has become very popular in recent years, especially 
their use as sweeteners (or dietary supplements) for producing soft drinks and energy drinks, tabletop sweeteners, dairy products, fruit/vegetable products, chewing gum, soups, and sauces (Lemus-Mondaca and others 2012).

Apart from their low GI, stevioside-based sweeteners, allowed in the EU since 2011, are also characterized by good heat stability (up to $140{ }^{\circ} \mathrm{C}$ ) and low degradation in both acidic and alkaline environments ( $\mathrm{pH}$ range 2 to 10), and they act protectively against the degradation of water-soluble vitamins such as ascorbic acid (Kroyer 2010), present in ice creams containing fruit pulp rich in ascorbic acid. Jooken and others (2012), investigating the stability of steviol glycosides in different foods, including ice cream, reported no detectable degradation of steviol glycosides in ice creams stored at $-18{ }^{\circ} \mathrm{C}$ for $12 \mathrm{wk}$. Nevertheless, steviol glycosides cannot totally replace sucrose (due to adverse effects on texture, flavor, and taste features), though they allow to reduce sugar content by up to $30 \%$ (from $22.8 \%$ to $16 \% \mathrm{w} / \mathrm{w}$ ). Blending steviol glycosides with polyols (maltitol and erythritol) has been a good strategy for ice cream reformulation without impairing mouthfeel, taste, body, and texture (Jooken and others $\underline{2012})$. Giri and others (2013) reported that producing low-sugar-content ice cream $(6.5 \%$ $\mathrm{w} / \mathrm{w})$ was feasible by adding steviol glycosides $(0.05 \% \mathrm{w} / \mathrm{w})$, while adverse effects of reducing the sugar content (crystallization and recrystallization phenomena, melting rate, hardness, and sensory traits) can be modulated by adding whey protein concentrate.

Ice cream reformulation using a patented low-GI blend (Trutina Dulcem®) composed of a fruit (kiwi), glycosides (steviosides, steviol glucosides, rebaudiosides, glycyrrhizin, mogroside V, and so on), and a low GI carbohydrate (fructose and polyols) has been successfully demonstrated (de Wees Allen 2008; de Wees Allen 2009). Postprandial in-vivo testing of sweet terpenoid glycoside ice creams in adults with or without diabetes symptoms revealed in both cases very low GI and glycemic load (GL) values, varying from 21 to 24 and 1.8 to 2.1, respectively (serving size $55 \mathrm{~g}$ ). Moreover, the inventor reported that the presence of Trutina Dulcem in the ice cream did not modify significantly its sensory profile, exhibiting good consumer acceptability, not stimulating fat storage in adipose tissue in both groups.

Ryu and others (2002) developed a method to produce a pulverized mulberry leaf extract product rich in bioactive compounds. The product, having a bland taste and flavor, was incorporated in ice creams at concentrations varying from $0.5 \%$ to $5 \% \mathrm{w} / \mathrm{w}$. Sensory profiling of the mulberry-leaf-containing ice cream showed improved primary organoleptic features, taste, mouthfeel, and overall acceptability (when added at $0.5 \%$ to $2.0 \% \mathrm{w} / \mathrm{w}$ ). Postprandial monitoring of the plasma glucose levels of 10 healthy subjects revealed a lower glucose blood appearance $45 \mathrm{~min}$ after ingestion in the case of ice creams enriched with mulberry leaf extract. It can be assumed that part of the activity was due to the presence of polyphenols, inhibiting glucose uptake from the gut (Ryu and others 2002).

\section{Natural Antioxidants}

\section{Overview}

Vegetable- and fruit-based food products and their by-products, cereals, pseudocereals, pulses, flours, tea and herbal teas, herb or spice extracts, cold-pressed oils, and so on, are some of the most common food items containing high amounts of antioxidant compounds such as polyphenols, carotenoids, tocopherols, tocotrienols, glutathione, ascorbic acid, and 
enzymes with antioxidant activity (Boskou 2006; Oreopoulou and Tzia 2006; Pellegrini and others 2008; Ogunlade and others 2009). It is well appreciated that adoption of a diet rich in natural antioxidants appears to be inversely associated with degenerative chronic diseases such as cardiovascular disease, cancer, obesity, and diabetes, as well as with the prevention of general inflammatory health implications and improvements of blood lipids such as cholesterol (Wilcox and others 2004; Bohn 2008).

Although interest in exploiting frozen dairy desserts as a carrier for these bioactive plant compounds against oxidative stress- and inflammation-related diseases has been increasing over the last few years, processing and food quality challenges must be overcome. For instance, several antioxidant compounds are considered as nonnutritive or even antinutritive, susceptible, or unstable under common processing practices such as for ice creams (heat treatment, aeration, and frozen storage), leading not only to partial loss of their physiological activity but also to food discoloration, development of off-flavor and aftertaste, and triggering lipid oxidation reactions. Thus, selection of antioxidants for ice cream prototyping is considered a rather challenging and laborious process.

\section{Vanilla-based extracts}

Undoubtedly, vanilla extract is the most common product with potential antioxidant activity used for ice cream production (Marshall and others 2003; Tai and others 2011). Typically, the vanillin amounts in ice cream products range from 5 to 100 ppm (Burdock 2005). Thus, vanilla, apart from its dominating role as flavoring in frozen dairy desserts (Cadena and others 2012), may also exert a fair antioxidant activity, enhancing ice cream resistance against light- or oxygen-induced oxidation that may result in flavor and aroma defects such as metallic, rancid, and cardboard off-notes (Shiota and others 2002). Vanilla extract components such as p-hydroxybenzoic acid, p-hydroxybenzaldehyde, vanillic acid, and vanillin have been held responsible for the potent antioxidant role of vanilla (Charles 2013). According to Kamat and others (2000), vanillin can provide sufficient protection against protein oxidation and lipid peroxidation occurring in rat liver mitochondria. Dietary vanillin $(1.25$ to $50 \mathrm{ppm})$ also exerted a significant hypotriglyceridemic effect in high-fat fed animals at all levels tested, and at the highest concentration a remarkable reduction of body weight and perirenal adipose tissue was detected (Srinivasan and others 2008). Tai and others (2011) demonstrated that vanillin $(20 \mu \mathrm{M})$ exhibits a stronger antioxidant capacity than ascorbic acid $(20 \mathrm{mM})$ using different multiple assays such as 2,2-azino-bis(3-ethylbenzothiazoline-6sulfonic acid) diammonium salt (ABTS $\bullet^{+}$) scavenging, ORAC, and oxidative hemolysis inhibition (OxHLIA). Moreover, vanillin (100 ppm) oral administration to mice resulted in detectable amounts of vanillin and its metabolites in plasma and a high antioxidant activity in the ORAC plasma assay. Recently, the ability of vanilla pod extracts (using supercritical fluids) to regulate cholesterol metabolism via upregulating the low-density lipoprotein receptor (LDLR) gene and downregulating the 3-hydroxy-3-methylglutaryl-coenzyme A reductase (HMGCR) gene in liver hepatocellular carcinoma (HepG2) cell lines was demonstrated (Al-Naqeb and others 2010). In addition, Makni and others (2011) studied the antioxidant, anti-inflammatory, and hepatoprotective properties of vanillin in carbontetrachloride-treated rats. It was found that vanillin pretreatment of rats prior to $\mathrm{CCl}_{4}$ administration inhibited hepatic lipid peroxidation and protein carbonyl formation in the liver. Moreover, based on liver histopathology results, vanillin attenuated the expression of proinflammatory cytokines such as tumor necrosis factor $\alpha$ (TNF- $\alpha)$, interleukin-1 $\beta$ (IL-1 $)$, and interleukin-6 (IL-6), preventing hepatic cell alteration and necrosis (Makni and others 
2011). Nonetheless, the potential health benefits associated with ingesting vanillin in ice cream need to be clinically proven.

Vanillin can also promote free radical scavenging action in food products, providing an effective strategy to control quality loss due to lipid oxidation. Based on early considerations, the addition of pure or concentrated vanilla pod extracts, or synthetic vanilla flavorings was able to hinder oxygen uptake from unsaturated fatty acids and phospholipids after 12 mo of storage of spray-dried ice cream powders (Pyenson and Tracy 1950). Similarly, Gassenmeier (2003) reported that vanillin addition to ice cream mixes after heat treatment improved their stability against autooxidation, responsible for the development of cardboard off-flavors. This was mainly attributed to the inactivation of xanthine oxidase, known to catalyze the oxidation of vanillin to vanillic acid.

\section{Fruits and fruit-based products}

Incorporation of fruit preparations (fruit juices, purees, or concentrates) into frozen dairy desserts has been verified as an alternative strategy to increase their phenolic content (Table 3 ). Addition of frozen wild blueberry puree $(5.33 \% \mathrm{w} / \mathrm{w})$ and juice concentrate $(4.92 \%$ to $5.33 \% \mathrm{w} / \mathrm{w}$ ) was reported as an adequate means to deliver antioxidant functionality in soymilk-based ice cream without affecting consumer acceptability (Camire and others 2006). Favaro-Trindade and others (2006) demonstrated that ice cream could be an excellent vehicle for delivering combined probiotic-antioxidant functionality by blending acerola fruit juice into ice cream mix fermented by Bifidobacteria. This allowed retaining living cell counts and ascorbic acid levels under prolonged frozen storage without altering flavor, taste, and texture. Sun-Waterhouse and others (2013) studied the effects of 3 different varieties of kiwifruit (green, yellow, and red flesh) added to regular ice cream, and they claimed potent health benefits due to the presence of several bioactive compounds, including ascorbic acid, caffeic acid, catechins, carotenoids (lutein and beta-carotene), salicylic acid, and o-coumaric acid. Moreover, favorable effects were also obtained in terms of rheological behavior, melting resistance, and overrun of the final product, with the red-flesh kiwifruit-supplemented food systems considered as the most acceptable. Recently, it was demonstrated that adding persimmon fruit puree to ice cream contributed to significant improvement of its total phenolic content and 2,2-diphenyl-1-picrylhydrazyl (DPPH) scavenging activity (Karaman and others 2014). In the same study, implementing the technique for order of preference by similarity to ideal solution (TOPSIS) approach, it was shown that sensory properties accounted for $80 \%$ of consumer preference response compared to $20 \%$ in the case of the health-promoting claims. It was deduced that $24 \% \mathrm{w} / \mathrm{w}$ ice cream enrichment with persimmon puree can satisfactorily meet both the criteria of acceptable organoleptic characteristics and antioxidant activity. On the other hand, Teh and others (2005) demonstrated that reducing the fat content of ice cream supplemented with blueberry concentrate had no significant effect on the amount of anthocyanins, ferrulic acid, and phenolic compounds, which depended exclusively on the amount of the added fruit preparation and thus highlighting that combining fruit preparations with ice cream constitutes a suitable carrier for health beneficial ingredients.

Table 3. Impact of ingredients containing natural antioxidants on antioxidant activity, technological, and organoleptic properties of ice cream 


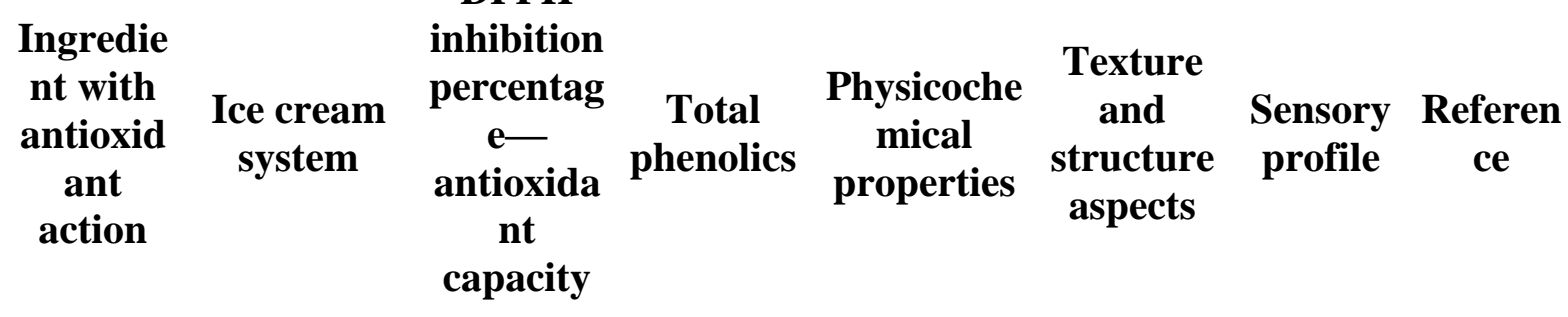

1. $\mathrm{DPPH}=\operatorname{di}($ phenyl) $)(2,4,6$-trinitrophenyl)iminoazanium, $\mathrm{Nd}=$ not determined (no data).

\begin{tabular}{|c|c|c|c|c|c|c|c|}
\hline $\begin{array}{l}\text { Pomegra } \\
\text { nate peel } \\
\text { extract } \\
(\mathrm{PPE})\end{array}$ & $\begin{array}{l}\text { Ice cream } \\
\text { with } 0.1 \% \text { or } \\
0.4 \% \mathrm{w} / \mathrm{w} \\
\text { PPE }\end{array}$ & $\begin{array}{l}4.9 \% \text { in } \\
\text { control } \\
52.5 \% \text { and } \\
99 \% \text { for } \\
\text { ice cream } \\
\text { with PPE }\end{array}$ & $\begin{array}{l}\text { n.d. in } \\
\text { control } 73 \\
\text { and } 363 \\
\mathrm{mg} / 100 \mathrm{~g} \\
\text { for ice } \\
\text { cream } \\
\text { with } 0.1 \% \\
\text { and } 0.4 \% \\
\text { PPE }\end{array}$ & $\begin{array}{l}\text { Decrease of } \\
\mathrm{pH}\end{array}$ & $\mathrm{Nd}$ & $\begin{array}{l}\text { Impart } \\
\text { sourness, } \\
\text { astringenc } \\
\text { y and } \\
\text { unnatural } \\
\text { flavor No } \\
\text { impact on } \\
\text { textural } \\
\text { aspects } \\
\text { Decrease } \\
\text { of } \\
\text { palatabilit } \\
\text { y and } \\
\text { sweetness }\end{array}$ & $\begin{array}{l}\text { Çam } \\
\text { and } \\
\text { others } \\
(\underline{2013)}\end{array}$ \\
\hline $\begin{array}{l}\text { Pomegra } \\
\text { nate peel } \\
\text { extract }\end{array}$ & $\begin{array}{l}\text { Ice cream } \\
\text { with } 0.5 \% \text { or } \\
1.0 \% \text { w/w of } \\
\text { microencaps } \\
\text { ulated PPE }\end{array}$ & $\begin{array}{l}\text { n.d. in } \\
\text { control } \\
243 \text { and } \\
133\left(E C_{50},\right. \\
\text { g of ice } \\
\text { cream/g } \\
\text { DPPH })\end{array}$ & $\begin{array}{l}\text { n.d. in } \\
\text { control } \\
327 \text { and } \\
893 \\
\mathrm{mg} / 100 \mathrm{~g} \\
\text { for ice } \\
\text { cream } \\
\text { with } 0.5 \% \\
\text { and } 1 \% \\
\text { PPE }\end{array}$ & $\mathrm{Nd}$ & $\mathrm{Nd}$ & $\begin{array}{l}\text { No impact } \\
\text { on } \\
\text { consumer } \\
\text { s' } \\
\text { acceptabil } \\
\text { ity No } \\
\text { perceivabl } \\
\text { e defects } \\
\text { relating to } \\
\text { PPE } \\
\text { addition }\end{array}$ & $\begin{array}{l}\text { Çam } \\
\text { and } \\
\text { others } \\
(\underline{2014})\end{array}$ \\
\hline $\begin{array}{l}\text { Pomegra } \\
\text { nate peel } \\
\text { extract }\end{array}$ & $\begin{array}{l}\text { Probiotic ice } \\
\text { cream with } \\
0.4 \% \text { w/w } \\
\text { PPE }\end{array}$ & $\begin{array}{l}\text { approxima } \\
\text { tely } 55 \% \\
\text { for control } \\
\text { approxima } \\
\text { tely } 80 \% \\
\text { for ice } \\
\text { cream } \\
\text { with PPE }\end{array}$ & $\begin{array}{l}\text { approxima } \\
\text { tely } 30 \\
\mathrm{mg} / \mathrm{g} \text { for } \\
\text { control } \\
\text { approxima } \\
\text { tely } 540 \\
\mathrm{mg} / \mathrm{g} \text { for } \\
\text { ice cream } \\
\text { with PPE }\end{array}$ & $\mathrm{Nd}$ & $\mathrm{Nd}$ & $\begin{array}{l}\text { No impact } \\
\text { on tested } \\
\text { sensory } \\
\text { aspects } \\
\text { (color, } \\
\text { texture, } \\
\text { flavor, } \\
\text { taste, and } \\
\text { overall } \\
\text { acceptabil } \\
\text { ity) }\end{array}$ & $\begin{array}{l}\text { Sagdic } \\
\text { and } \\
\text { others } \\
(\underline{2012)})\end{array}$ \\
\hline $\begin{array}{l}\text { Grape } \\
\text { seed }\end{array}$ & $\begin{array}{l}\text { Probiotic ice } \\
\text { cream with }\end{array}$ & $\begin{array}{l}\text { approxima } \\
\text { tely } 55 \% \\
\text { for control }\end{array}$ & $\begin{array}{l}\text { approxima } \\
\text { tely } 30 \\
\mathrm{mg} / \mathrm{g} \text { for }\end{array}$ & $\mathrm{Nd}$ & $\mathrm{Nd}$ & $\begin{array}{l}\text { No impact } \\
\text { on tested }\end{array}$ & $\begin{array}{l}\text { Sagdic } \\
\text { and }\end{array}$ \\
\hline
\end{tabular}




\begin{tabular}{|c|c|c|c|c|c|c|c|}
\hline $\begin{array}{l}\text { Ingredie } \\
\text { nt with } \\
\text { antioxid } \\
\text { ant } \\
\text { action }\end{array}$ & $\begin{array}{l}\text { Ice cream } \\
\text { system }\end{array}$ & $\begin{array}{c}\text { inhibition } \\
\text { percentag } \\
\text { e- } \\
\text { antioxida } \\
\text { nt } \\
\text { capacity }\end{array}$ & $\begin{array}{c}\text { Total } \\
\text { phenolics }\end{array}$ & $\begin{array}{l}\text { Physicoche } \\
\text { mical } \\
\text { properties }\end{array}$ & $\begin{array}{c}\text { Texture } \\
\text { and } \\
\text { structure } \\
\text { aspects }\end{array}$ & $\begin{array}{c}\text { Sensory } \\
\text { profile }\end{array}$ & $\begin{array}{c}\text { Referen } \\
\text { ce }\end{array}$ \\
\hline $\begin{array}{l}\text { extract } \\
\text { (GSE) }\end{array}$ & $\begin{array}{l}0.4 \% \text { w/w } \\
\text { GSE }\end{array}$ & $\begin{array}{l}\text { approxima } \\
\text { tely } 68 \% \\
\text { for ice } \\
\text { cream } \\
\text { with GSE }\end{array}$ & $\begin{array}{l}\text { control } \\
\text { approxima } \\
\text { tely } 370 \\
\mathrm{mg} / \mathrm{g} \text { for } \\
\text { ice cream } \\
\text { with GSE }\end{array}$ & & & $\begin{array}{l}\text { sensory } \\
\text { aspects }\end{array}$ & $\begin{array}{l}\text { others } \\
\text { (2012) }\end{array}$ \\
\hline $\begin{array}{l}\text { Pomegra } \\
\text { nate seed } \\
\text { oil (PSO) }\end{array}$ & $\begin{array}{l}\text { Ice cream } \\
\text { with } 2 \% \text { or } \\
4 \% \text { w/w PSO }\end{array}$ & $\begin{array}{l}4.9 \% \text { in } \\
\text { control } \\
5.8 \% \text { and } \\
8.2 \% \text { for } \\
\text { ice cream } \\
\text { with PSO }\end{array}$ & $\begin{array}{l}\text { n.d. in } \\
\text { control } \\
69.4 \text { and } \\
66.3 \\
\mathrm{mg} / 100 \mathrm{~g} \\
\text { for ice } \\
\text { cream } \\
\text { with } 0.1 \% \\
\text { and } 0.4 \% \\
\text { PSO }\end{array}$ & $\begin{array}{l}\text { No impact } \\
\text { on } \mathrm{pH}\end{array}$ & $\mathrm{Nd}$ & $\begin{array}{l}\text { Impart } \\
\text { astringenc } \\
\text { y, } \\
\text { oxidized, } \\
\text { and } \\
\text { unnatural } \\
\text { off- } \\
\text { flavors } \\
\text { Decrease } \\
\text { of } \\
\text { palatabilit } \\
\text { y }\end{array}$ & $\begin{array}{l}\text { Çam } \\
\text { and } \\
\text { others } \\
(\underline{2013)}\end{array}$ \\
\hline $\begin{array}{l}\text { Peppermi } \\
\text { nt } \\
\text { essential } \\
\text { oil } \\
\text { (PEO) }\end{array}$ & $\begin{array}{l}\text { Probiotic ice } \\
\text { cream with } \\
0.03 \% \mathrm{w} / \mathrm{w} \\
\text { PEO }\end{array}$ & $\begin{array}{l}\text { Approxim } \\
\text { ately } 55 \% \\
\text { for control } \\
\text { approxima } \\
\text { tely } 52 \% \\
\text { for ice } \\
\text { cream } \\
\text { with PEO }\end{array}$ & $\begin{array}{l}\text { Approxim } \\
\text { ately } 30 \\
\mathrm{mg} / \mathrm{g} \text { for } \\
\text { control } \\
\text { approxima } \\
\text { tely } 50 \\
\mathrm{mg} / \mathrm{g} \text { for } \\
\text { ice cream } \\
\text { with PEO }\end{array}$ & $\mathrm{Nd}$ & $\mathrm{Nd}$ & $\begin{array}{l}\text { No impact } \\
\text { on tested } \\
\text { sensory } \\
\text { aspects }\end{array}$ & $\begin{array}{l}\text { Sagdic } \\
\text { and } \\
\text { others } \\
(\underline{2012)}\end{array}$ \\
\hline $\begin{array}{l}\text { Herbal } \\
\text { tea }\end{array}$ & $\begin{array}{l}\text { Ice cream } \\
\text { containing } \\
2.5 \% \text { or } 5 \% \\
\text { w/w black } \\
\text { tea, sage, } \\
\text { linden, or } \\
\text { chamomile } \\
\text { extracts } \\
\text { (water } \\
\text { extraction at } \\
40 \text { or } 80{ }^{\circ} \mathrm{C} \text { ) }\end{array}$ & $\begin{array}{l}\text { Not } \\
\text { reported }\end{array}$ & $\begin{array}{l}\text { Approxim } \\
\text { ately } 100 \\
\mathrm{mg} / \mathrm{kg} \text { for } \\
\text { control } \\
\text { approxima } \\
\text { tely } 175 \text { to } \\
415 \mathrm{mg} / \mathrm{kg} \\
\text { for black } \\
\text { tea } \\
\text { approxima } \\
\text { tely } 165 \text { to } \\
260 \mathrm{mg} / \mathrm{kg} \\
\text { for sage } \\
\text { approxima } \\
\text { tely } 180 \text { to }\end{array}$ & $\begin{array}{l}\text { No } \\
\text { significant } \\
\text { impact on } \\
\text { pH and } \\
\text { acidity } \\
\text { Decrease of } \\
\text { pseudoplasti } \\
\text { city and } \\
\text { consistency } \\
\text { coefficient }\end{array}$ & $\begin{array}{l}\text { Reduced } \\
\text { air } \\
\text { incorporat } \\
\text { ion in } \\
\text { herbal tea } \\
\text { extract } \\
\text { containing } \\
\text { samples }\end{array}$ & $\begin{array}{l}\text { Acceptabl } \\
\text { e taste, } \\
\text { odour, } \\
\text { color, and } \\
\text { appearanc } \\
\text { e } \\
\text { characteri } \\
\text { stics in } \\
\text { ice } \\
\text { creams } \\
\text { with } \\
\text { linden or } \\
\text { chamomil } \\
\text { e Adverse } \\
\text { impact on }\end{array}$ & $\begin{array}{l}\text { Karama } \\
\text { n and } \\
\text { Kayacie } \\
\text { r (2012) }\end{array}$ \\
\hline
\end{tabular}




\begin{tabular}{|c|c|c|c|c|c|c|c|}
\hline $\begin{array}{l}\text { Ingredie } \\
\text { nt with } \\
\text { antioxid } \\
\text { ant } \\
\text { action }\end{array}$ & $\begin{array}{l}\text { Ice cream } \\
\text { system }\end{array}$ & $\begin{array}{c}\text { inhibition } \\
\text { percentag } \\
\text { e- } \\
\text { antioxida } \\
\text { nt } \\
\text { capacity }\end{array}$ & $\begin{array}{c}\text { Total } \\
\text { phenolics }\end{array}$ & $\begin{array}{l}\text { Physicoche } \\
\text { mical } \\
\text { properties }\end{array}$ & $\begin{array}{l}\text { Texture } \\
\text { and } \\
\text { structure } \\
\text { aspects }\end{array}$ & $\begin{array}{c}\text { Sensory } \\
\text { profile }\end{array}$ & $\begin{array}{c}\text { Referen } \\
\text { ce }\end{array}$ \\
\hline & & & $\begin{array}{l}340 \mathrm{mg} / \mathrm{kg} \\
\text { for linden } \\
\text { approxima } \\
\text { tely } 120 \text { to } \\
185 \mathrm{mg} / \mathrm{kg} \\
\text { for } \\
\text { chamomile }\end{array}$ & & & $\begin{array}{l}\text { organolep } \\
\text { tic quality } \\
\text { on black } \\
\text { tea or } \\
\text { sage } \\
\text { addition }\end{array}$ & \\
\hline $\begin{array}{l}\text { Grape } \\
\text { wine lees } \\
(\mathrm{GWL})\end{array}$ & $\begin{array}{l}\text { Ice cream } \\
\text { with } 0.5 \% \text {, } \\
1 \%, 2 \% \text {, or } \\
4 \% \text { w/w of } \\
\text { GWL }\end{array}$ & $\begin{array}{l}1.59 \mathrm{mg} / \mathrm{g} \\
\text { for control } \\
1.65 \text { to } \\
1.95 \mathrm{mg} / \mathrm{g} \\
\text { for } \\
\text { systems } \\
\text { with } \mathrm{GWL}\end{array}$ & $\begin{array}{l}0.018 \\
\mathrm{mg} / \mathrm{g} \text { for } \\
\text { control } \\
0.11 \text { to } \\
0.40 \mathrm{mg} / \mathrm{g} \\
\text { for } \\
\text { systems } \\
\text { with } \mathrm{GWL}\end{array}$ & $\begin{array}{l}\text { Increase of } \\
\text { acidity } \\
\text { Improved } \\
\text { melting } \\
\text { resistance }\end{array}$ & $\mathrm{Nd}$ & $\begin{array}{l}\text { Flavor, } \\
\text { taste, } \\
\text { texture, } \\
\text { and body } \\
\text { scores } \\
\text { were } \\
\text { maximize } \\
\text { d at } 2 \% \\
\text { GWL }\end{array}$ & $\begin{array}{l}\text { Sharma } \\
\text { and } \\
\text { others } \\
(\underline{2013)}\end{array}$ \\
\hline $\begin{array}{l}\text { Grape } \\
\text { wine lees }\end{array}$ & $\begin{array}{l}\text { Ice cream } \\
\text { with } 5 \% \text {, } \\
10 \% \text {, and } \\
15 \% \text { w/w of } \\
\text { GWL }\end{array}$ & $\begin{array}{l}18 \% \text { for } \\
\text { control } \\
46 \% \text { to } \\
68 \% \text { for } \\
\text { systems } \\
\text { with GWL }\end{array}$ & $\begin{array}{l}1.5 \mathrm{mg} / \mathrm{mL} \\
\text { for control } \\
2.3 \text { to } 3.3 \\
\text { for system } \\
\text { with } \mathrm{GWL}\end{array}$ & $\begin{array}{l}\text { Reduction } \\
\text { of overrun } \\
\text { Improvemen } \\
\text { t of viscosity } \\
\text { Reduction } \\
\text { of pH } \\
\text { Reduction } \\
\text { of ice fusion } \\
\text { enthalpy }\end{array}$ & $\begin{array}{l}\text { Increase } \\
\text { of fat } \\
\text { destabiliza } \\
\text { tion } \\
\text { index-fat } \\
\text { droplets } \\
\text { mean size } \\
\text { Reduction } \\
\text { of } \\
\text { firmness } \\
\text { and } \\
\text { cohesiven } \\
\text { ess }\end{array}$ & $\mathrm{Nd}$ & $\begin{array}{l}\text { Hwang } \\
\text { and } \\
\text { others } \\
(\underline{2009)})\end{array}$ \\
\hline $\begin{array}{l}\text { Kiwifruit } \\
\text { juice }\end{array}$ & $\begin{array}{l}\text { Ice cream } \\
\text { containing } \\
49 \% \mathrm{v} / \mathrm{v} \\
\text { green, gold, } \\
\text { or red flesh } \\
\text { kiwifruit } \\
\text { juice }\end{array}$ & $\begin{array}{l}0.136, \\
0.208, \text { and } \\
0.338 \\
\text { Trolox eq. } \\
\mathrm{mg} / \mathrm{g} \text { for } \\
\text { ice cream } \\
\text { with } \\
\text { green, } \\
\text { gold, and } \\
\text { red flesh } \\
\text { kiwifruit } \\
\text { juice }\end{array}$ & $\begin{array}{l}193,232, \\
\text { and } 399 \\
\text { mg/kg for } \\
\text { ice cream } \\
\text { with } \\
\text { green, } \\
\text { gold, and } \\
\text { red flesh } \\
\text { kiwifruit } \\
\text { juice }\end{array}$ & $\begin{array}{l}\text { Improved } \\
\text { melting } \\
\text { resistance } \\
\text { and higher } \\
\text { overrun in } \\
\text { ice cream } \\
\text { with red } \\
\text { flesh } \\
\text { kiwifruit } \\
\text { juice }\end{array}$ & $\begin{array}{l}\text { Storage } \\
\text { modulus } \\
\left(G^{\prime}\right) \text { and } \\
\text { fat } \\
\text { destabiliza } \\
\text { tion index } \\
\text { were } \\
\text { higher at } \\
\text { red-gold } \\
\text { kiwifruit } \\
\text { juice ice } \\
\text { cream }\end{array}$ & $\mathrm{Nd}$ & $\begin{array}{l}\text { Sun- } \\
\text { Waterho } \\
\text { use and } \\
\text { others } \\
(\underline{2013})\end{array}$ \\
\hline
\end{tabular}




\begin{tabular}{|c|c|c|c|c|c|c|c|}
\hline $\begin{array}{l}\text { Ingredie } \\
\text { nt with } \\
\text { antioxid } \\
\text { ant } \\
\text { action }\end{array}$ & $\begin{array}{l}\text { Ice cream } \\
\text { system }\end{array}$ & $\begin{array}{c}\text { DPPH } \\
\text { inhibition } \\
\text { percentag } \\
\text { e- } \\
\text { antioxida } \\
\text { nt } \\
\text { capacity }\end{array}$ & $\begin{array}{c}\text { Total } \\
\text { phenolics }\end{array}$ & $\begin{array}{l}\text { Physicoche } \\
\text { mical } \\
\text { properties }\end{array}$ & $\begin{array}{c}\text { Texture } \\
\text { and } \\
\text { structure } \\
\text { aspects }\end{array}$ & $\begin{array}{c}\text { Sensory } \\
\text { profile }\end{array}$ & $\begin{array}{c}\text { Referen } \\
\text { ce }\end{array}$ \\
\hline $\begin{array}{l}\text { Persimm } \\
\text { on puree }\end{array}$ & $\begin{array}{l}\text { Ice cream } \\
\text { containing } \\
8 \%, 16 \% \text {, } \\
24 \%, 32 \% \text {, or } \\
40 \% \mathrm{w} / \mathrm{w} \\
\text { persimmon } \\
\text { puree }\end{array}$ & $\begin{array}{l}20 \% \text { for } \\
\text { control } \\
40 \% \text { to } \\
65 \% \text { for } \\
\text { persimmo } \\
\text { n puree } \\
\text { based } \\
\text { systems }\end{array}$ & $\begin{array}{l}\text { Approxim } \\
\text { ately } 750 \\
\mathrm{mg} / \mathrm{kg} \text { for } \\
\text { control } \\
\text { approxima } \\
\text { tely } 975 \text { to } \\
1650 \\
\mathrm{mg} / \mathrm{kg} \text { for } \\
\text { persimmo } \\
\mathrm{n} \text { puree } \\
\text { based } \\
\text { systems }\end{array}$ & $\begin{array}{l}\text { Enhanced } \\
\text { melting } \\
\text { resistance } \\
\text { No impact } \\
\text { on pH } \\
\text { Reduction } \\
\text { of mixes' } \\
\text { viscosity }\end{array}$ & $\begin{array}{l}\text { Lower } \\
\text { hardness, } \\
\text { work of } \\
\text { penetratio } \\
\mathrm{n} \text {, and } \\
\text { stickiness } \\
\text { of } \\
\text { persimmo } \\
\text { n puree } \\
\text { based } \\
\text { systems }\end{array}$ & $\begin{array}{l}\text { Improvem } \\
\text { ent of } \\
\text { melting } \\
\text { quality } \\
\text { Adverse } \\
\text { effect on } \\
\text { taste on } \\
\text { overall } \\
\text { acceptabil } \\
\text { ity and } \\
\text { taste } \\
\text { (24\% the } \\
\text { most } \\
\text { acceptabl } \\
\text { e) No } \\
\text { impact on } \\
\text { odour, } \\
\text { color, and } \\
\text { structure } \\
\text { aspects }\end{array}$ & $\begin{array}{l}\text { Karama } \\
\mathrm{n} \text { and } \\
\text { others } \\
(2014)\end{array}$ \\
\hline
\end{tabular}

\section{Agricultural waste products}

Waste products of the agri-food industry such as molasses or pomace are generally regarded as good sources for bioactive compounds, including natural antioxidants (Ayala-Zavala and others 2011). Despite technological obstacles, in order to overcome exploiting food waste (mainly costs of drying, storage, and transport), their often high content of a broad range of bioactives and micronutrients renders their exploitation for food production purposes attractive (Oreopoulou and Tzia 2006). Important benefits have been revealed by the supplementation of ice cream with grape wine lees, a common winery waste rich in polyphenols and DF that is easily fermented by human intestinal host bacteria (Toping and Clifton 2001; Hwang and others 2009). Hwang and others (2009) evaluated the impact of wine grape lees solids addition $(5 \%, 10 \%$, or $15 \% \mathrm{w} / \mathrm{w})$ to ice creams, concluding that $5 \%$ $\mathrm{w} / \mathrm{w}$ of wine grape less may improve rheological characteristics, reduce the freezable content and melting rate without influencing fat destabilization and air incorporation phenomena, while delivering important amounts of polyphenolics such as anthocyanins.

Recently, the feasibility to use pomegranate (Punica granatum L.) peel by-products (PBP) rich in phenolic compounds and PUFAs for producing functional ice cream was investigated (Çam and others 2013; Çam and others 2014). According to the findings of Çam and others (2013) adding PBP (at $0.1 \%$ and $0.4 \% \mathrm{w} / \mathrm{w}$ ) was accompanied by a significant increase of phenolic compounds (mainly punicalagin, ellagic acid, and their derivatives), which was 
associated with higher DPPH-scavenging activity and more effective inhibition of $\alpha$ glucosidase activity, the latter reducing the GI of prepared formulations. Similarly, enhanced antioxidant activity was also found following the addition of pomegranate seed oil (PSO) to ice cream (Çam and others 2013). In a subsequent study, Çam and others (2014) indicated that the antioxidant and $\alpha$-glucosidase-inhibiting action of PBP-entrapped in maltodextrinspray-dried matrices, compared to native PBP, were not significantly affected. In addition, microencapsulation of PBP appeared to be a good strategy for overcoming restrictions related to adverse organoleptic properties resulting from the presence of phenolics, such as astringency, unsatisfactory tongue lubrication, and oral mucosa puckering (Çam and others 2014).

The addition of whey protein isolate (WPI) glycated with the sugars D-allose and D-psicose into ice cream has been referred to as a novel way for delivering excellent antioxidant properties together with improving foaming and emulsifying capacity (Puangmanee and others 2008). The authors suggested that free radical scavenging activity for the specific formulations was associated with the conjugation of Maillard reaction products found in WPI with the C-3 hydroxyl group of these sugars.

\section{Herbal extracts}

Herbal or green tea extracts were found to constitute suitable ingredients to increase the phenolic content of ice creams. In a study by Karaman and Kayacier (2012), the use of brewed black and herbal teas (chamomile, linden, and sage) at 2 temperatures for the production of ice cream suggested that antioxidant activity was both dependent on tea type and brewing temperature, with black tea or linden brewed at $80{ }^{\circ} \mathrm{C}$ resulting in the highest antioxidant activity of ice cream. The same authors also highlighted that the used herbal tea extracts may also confer important antimicrobial effects (against Listeria monocytogenes) and viscosity enhancements, but in most cases, they were accompanied with moderate deterioration of flavor (astringency, sharpness, and bitterness) and color attributes of the final products (Ozturk and others 2010; Karaman and Kayacier 2012).

Using finely ground green tea (macha) in ice cream has also been utilized for increasing the antioxidant capacity of the final product, but a negative impact on textural organoleptic properties such as astringency, bitterness, formation of clumps, powdery texture, and insufficient air incorporation has been reported. In a recent attempt to overcome these drawbacks, Fukuda (2012) developed a novel ice cream formulation by incorporating nonpolymer catechins and caffeine at usage rate ranging from 0.001 to 0.18 . These systems exhibited very good air incorporation capacity and excellent texture and shape retention characteristics without adversely affecting the flavor of the product.

\section{Omega-3,6 Fatty Acids and Polyunsaturated Fatty Acids}

Omega-3 and $\omega-6$ fatty acids comprise 2 important classes of PUFAs that are most commonly represented by alpha-linolenic acid and linoleic acid, respectively. Over the last several years, great interest has been built up to incorporate natural food ingredients rich in these fatty acids into other food products to improve their nutritional profile. The major health benefits 
associated with adopting a diet rich in PUFAs are primarily associated with the prevention of cardiovascular disease, rheumatoid arthritis, cancer, and inflammation, lowering of blood pressure, reinforcement of the immune system, and contributions to brain and nervous systems (Simopoulos 1991; Arab-Tehrani and others 2012). Huang (2011) demonstrated that incorporating omega 3/6 fatty acid extracts from fish or oil from algae in dairy matrices can be used to prevent several oral infections or inflammatory diseases such as caries, periodontitis, gingivitis, mouth ulcers, and halitosis, due to their antimicrobial activity against many oral pathogens.

Recently, several applications of omega-3-rich-oils such as fish, flaxseed, rice bran, and algal oil in frozen dairy desserts were launched (Gonzalez and others 2003; Chee and others 2007; Huang 2011; Song and others 2011). Gonzalez and others (2003) demonstrated that ice cream produced with alpha-linolenic acid fortified milk resulted in low-viscosity ice cream mixes and softer frozen finished products without impacting oxidative alterations during storage. Similar results were also reported by Goh and others (2006); and (Méndez-Velasco and Goff 2012) who observed that a reduced milk fat to flaxseed oil ratio coincides with reduced product stiffness and melting resistance. This was mainly due to impaired structuring, that is, low partial fat coalescence during the freezing-whipping. The latter drawback may surpassed by intelligent structure design of ice cream emulsions (ratio of saturated to unsaturated fatty acids, saturation level of the emulsifying agents), high-pressure low-temperature freezing, or the implementation of the 2-phase process that is based on combining an emulsion (fat, some protein, and water) with an aqueous solution composed of sugar solids, stabilizers, and remaining protein (Segall and Goff 2002; Sung and Goff 2010; Song and others 2011; Méndez-Velasco and Goff 2012).

Oleogel technology (for example, use of organogelating agents to provide liquid edible oils with solid-like properties) is a technique that has recently been successfully applied for saturated fatty acid replacement by polyunsaturated ones (Zulim Botega and others 2013a, 2013b). According to Zulim Botega and others (2013a), rice bran wax (RBW) oleogels were effectively emulsified into ice cream mixes, promoting the formation of small gelled fat droplets, as well as showing sufficient protein absorption on oil-water interfaces and successive displacement by competitive surface-active agents. In addition, RBW oleogels enhanced air incorporation and structure formation upon freezing, behaving more like crystallized than liquid lipids (Zulim Botega and others 2013a). However, a proper design of the emulsifying system is required to prevent structural collapse during melting (Zulim Botega and others 2013b). Naturally extracted lipid-rich organelles from oil seeds such as sunflower (Helianthus annus) (oil bodies) with high oxidation stability (Fisk and others 2008) also have shown to be promising sources of PUFAs and as ice cream ingredients, potentially offering a source of oxidation-stable unsaturated fatty acids and additional surface active materials to the ice cream mix (Berry and others 2006).

Impairment organoleptic properties can be a restrictive parameter for their direct incorporation in frozen dairy desserts. Chee and others (2007) showed that consumer preference of omega 3/6-enriched regular ice creams is predominantly influenced by the flavoring system. It has been shown that strawberry flavoring can mask more effectively any fishy-like off-notes than vanilla flavoring (Chee and others 2007). In a recent study, Song and others (2011) incorporated omega-3 lipids in full-fat chocolate probiotic ice cream, demonstrating a perceivable deterioration of product acceptability, mainly due to the development of fishy off-flavors. However, it has also been shown that the presence of 
omega-3/6 fatty acids can promote survival of probiotic cells when subjected to freezeinduced or mechanical stress during freezing and storage.

The potential to deliver omega-3/6 fatty acids indirectly in dairy products, that is through modification of the diet of cows, has also been reported (Egger and others 2007). Using milk from cows fed with fodder supplemented with seed rich in PUFAs such as linseed, canola, cottonseed, and soybean has been proposed for producing smooth ice cream with improved nutritional value and nonperceivable flavor defects such as oxidized or rancid (Chen and others 2004). Feed fortification for milk enrichment with valuable fatty acids has also been proposed as a practice for dairy product enrichment including ice cream with conjugated linolenic acid (CLA) (Gonzalez and others 2003). According to recent considerations, the most representative isomers of CLA (9-cis, 10-trans, 11-trans, and 12-cis C18:2) appear to exert potent physiological actions such as being anticarcinogenic, antiobese, antidiabetic, and antihypertensive (Koba and Yanagita 2013), although results remain controversial. Systematic studies of CLA on structural, textural, and sensory properties of ice cream are scarce, it has been shown that CLA-rich milk fat can provide adequate texture and body qualities (similar to CLA-free milk-fat-based ice cream), despite reduced macroviscosity of the ice cream due to the solid to liquid fat ratio reduction (Gonzalez and others 2003). In the same study, it was pointed out that using CLA-rich milk fat did not appear to impact the lipid autoxidation reactions occurring during ice cream storage. In addition, it has been evidenced that the type of dairy matrix (milk, butter, or yogurt) can critically affect the perception thresholds of CLA-associated defects such as aftertaste, rancidity, acid, and nutty off-flavors (Jimenez and others 2008).

\section{Mineral and Trace Element Fortification}

As for milk and milk products, frozen dairy desserts are regarded as good sources of inorganic microconstituents and water-soluble vitamins (Marshall and others 2003). Most of the minerals found in ice cream are present in form of salts in the freeze-concentrated serum phase, except for calcium and phosphorus that exceed their solubility and associate with casein micelles. In addition, some of the trace elements may also be present as complexes with proteins, for example, lactoferrin $(\mathrm{Fe})$, or enzymes, like xanthine oxidoreductase $(\mathrm{Fe}$, Mo) (Walstra and others $\underline{2006}$ ).

Liposoluble vitamins (vitamin K, D, E, and A) are found at very low amounts in ice cream, while they are absent in low-fat and nonfat formulations (Marshall and others 2003). Thus, mineral and trace element ice cream fortification aims both toward improving the nutritional value and to compensate for losses occurring during processing and storage, particularly due to heat treatment and skimming (Marshall and others 2003). Calcium and iron ice cream fortification is very common although there is also a growing interest in fortification with other micronutrients such as magnesium, zinc, manganese, cobalt, nickel, copper, and provitamin A carotenoids (Noël and others 2012).

Ice cream is considered a good source of calcium $(836 \mathrm{mg} / \mathrm{kg})$, but with ranges much lower than that of other dairy products such as milk, cheese, or yogurt (Chekri and others 2012), due to the lower amount of milk in the final product. Nevertheless, ice cream is regarded as an excellent vehicle for calcium administration to different target groups. In a recent study, Ferrar and others (2011) have shown that consumption of calcium-fortified low-fat ice cream by a target population of young women with habitually low calcium intake significantly 
reduced bone calcium resorption over a 28-d period, without any increase in body weight. The addition of dairy minerals for calcium fortification purposes in ice creams has further been reported as an efficient strategy for improving the bioavailability of calcium, regardless of the compositional diversity of the formulations. Van der Hee and others (2009) reported a similar fractional calcium absorption from butterfat- or coconut oil-standardized ice creams compared to low-fat milk in young adults ( 25 to $45 \mathrm{y}$ ), about $26 \pm 8 \%$ compared with $31 \pm 8 \%$, respectively. It was deduced that changes in the long-chain saturated fatty acid (palmitic, oleic, and lauric) did not affect the intestinal absorption of calcium or the bone mineral mass.

Direct standardization of ice cream mixes prior to or during freezing-whipping has been proposed for mineral and water-soluble vitamin fortification of ice cream (Wendel 2010). Often, however, mineral standardization of ice cream using salts leads to significant technological and nutritional drawbacks, such as protein and mineral precipitation, color and flavor deterioration, development of mouthfeel defects (chalky and gritty texture), and reduction of heat stability and bioavailability (Augustin 2003). Several strategies to overcome this hurdle have been proposed, with microencapsulation of minerals in hydrocolloid-based carriers or liposomes or complexation with anionic polysaccharides (such as carrageenans, pectins, or alginates) being the most effective strategies (Augustin 2003). In addition, food matrices rich in bioactive compounds including minerals such as fruit juices or concentrates have been proposed as alternatives to increase mineral content. However, changes in organoleptic profile and colloidal aspects of the finished products may be encountered (Soukoulis and Tzia 2010; Dagdemir 2011; Erkaya and others 2012; Karaman and others $\underline{2014)}$.

Jacobson and others (2002) postulated that complexing calcium salts with hydrolyzed anionic polysaccharides (including pectins, cellulosics, and carrageenans) with a DP ranging from 50 to 80 contributes to the efficient control of protein destabilization, that is, coagulation and precipitation, due to the presence of free calcium ions. Calcium-polysaccharide complexes can be used to stabilize calcium-fortified ice cream mixes without imparting undesirable high viscosity, flavor, and palatability defects. On the other hand, Wedral and others (1998) demonstrated that complexation of soluble calcium salts (calcium gluconate, lactate, or chloride) with alkali metal citrate at a ratio of $1: 4$ to $4: 1$ can be used for ice cream fortification, retaining its colloidal stability. Augustin and Williams (2001) exploited the ability of calcium and/or other minerals (iron, zinc, magnesium, and manganese) to migrate into the casein micelles following the addition of an effective amount of phosphate. The method has been claimed to more efficiently binding minerals in the micellar state compared to chelating agents (that is, citrates and polyphosphates), which at high concentrations destabilize the casein micelles, thereby releasing soluble calcium into the serum phase. The authors revealed that ice cream made from fortified milk using the phosphate-induced mineral complexation approach exerted similar melting behavior and textural profile than that composed of nonfortified milk, while only minor differences in the perceived flavor traits were observed.

Incorporation of raisin and grape juice concentrates or sugar cane molasses has been reported as an efficient way to administer iron in regular chocolate ice cream without imparting textural defects or off-flavors (Soukoulis and Tzia 2010). Adding 5\% to 15\% (w/w) dried Cape gooseberry pulp in conventional ice creams may increase the concentration of several minor abundant minerals (Fe, Mn, Zn, and S) without affecting or only slightly decreasing major abundant minerals, $\mathrm{Ca}, \mathrm{P}, \mathrm{Mg}, \mathrm{K}$, and $\mathrm{Na}$ (Erkaya and others 2012). Similarly, the addition of $5 \%$ to $20 \%$ (w/w) vegetable marrow (Cucurbita pepo L.) pulp in ice cream was 
associated with a significant increase of $\mathrm{Zn}, \mathrm{K}$, and Fe content, though it induced a significant reduction of the concentration of major minerals, that is, Ca and $\mathrm{P}$ (Dağdemir 2011). Moreover, in both cases, the incorporation of Cape gooseberry or vegetable marrow was accompanied by a remarkable improvement of the viscosity, melting, and sensory quality (Erkaya and others 2012; Dağdemir 2011). Karaman and others (2014) studying the impact of persimmon puree on the mineral content of ice cream revealed a significant increase of $\mathrm{K}$ content, though a significant reduction of $\mathrm{Ca}$ and $\mathrm{Mg}$ concentration was also observed. The authors deduced that persimmon enriched ice cream could be a nutritious dairy-based analog for people suffering from hypertension.

\section{Conclusions}

Over the last decade, the sector of functional frozen dairy desserts has experienced a remarkable growth, driven primarily by the increasing consumer awareness for healthy, nutritious, and additive-free products without compromising distinctive quality features such as palatability, flavor, and texture. Due to its structural complexity and the moderately low processing intensity, ice cream is generally considered as a good substrate for incorporating a broad spectrum of bioactive compounds, including living organisms. On the other hand, the direct relationship between structural elements and markers of quality and storage stability may pose obstacles on convenient functional ice cream prototyping. Consequently, incorporating functional ingredients and bioactive compounds must be realized without adversely affecting the colloidal and structural integrity of ice cream (sufficient air incorporation and fat droplet destabilization, minimal impact on crystallization and recrystallization phenomena, control of unfrozen water molecular mobility and diffusivity, and compatibility of the added bioactive compounds with major compositional elements), flavor, and taste attributes, ensuring adequate stability of the bioactive compounds. Probiotics can generally be easily incorporated in ice cream due to their relatively minor impact on ice cream texture and storage stability. On the other hand, incorporating prebiotics, DF, and LGSs in ice cream is a challenging task due to their ability to influence the colligative and rheological properties of the mixes, and consequently, the structure and texture development as well as the colloidal changes during storage.

Employing naturally occurring antioxidants such as polyphenols and carotenoids from byproducts or in form of fruit preparations appears an effective strategy to promote ice cream quality and to drastically improve antioxidant (free radical scavenging, potentially reducing chronic health complications related to oxidative stress and inflammation) capacity of frozen dairy desserts. In addition, incorporating fruit preparations in ice cream can also ameliorate the mineral/trace element profile (for example, $\mathrm{Ca}, \mathrm{P}, \mathrm{Mg}, \mathrm{K}, \mathrm{Na}, \mathrm{Fe}$, and $\mathrm{Zn}$ ) and provide an all-natural flavor and color.

Despite the conceptualization and development of several types of functional ice cream products, the disclosure of specific health benefits and physiological actions for marketing purposes still remains very challenging due to legislation restrictions. In most cases, food bioactives incorporated into ice cream should be judged for their health benefits by government agencies, for example, EFSA, FDA, and so on, and evidence of the health benefits should originate from clinical trials. From this perspective, developing a holistic approach in the field of functional ice cream that will also include findings from in vivo and clinical studies apart from technological profile characterization appears to be a growing future trend. 
